\title{
Paleoecology, biogeography, and evolution of reef ecosystems in the Panthalassa Ocean during the Late Triassic: Insights from reef limestone of the Sambosan Accretionary Complex, Shikoku, Japan
}

Camille Peybernes, Jérôme Chablais, Tetsuji Onoue, Gilles Escarguel, Rossana Martini

C. Peybernes, R. Martini

University of Geneva, Department of Earth Sciences, rue des Maraîchers Geneva 1205, Switzerland

e-mail: camille.peybernes@unige.ch

\section{J. Chablais}

Geneva Petroleum Consultants International, Geneva 1211, Switzerland

T. Onoue

Department of Earth and Environmental Sciences, Kumamoto University, Kumamoto, 8608555 Japan

G. Escarguel

UMR CNRS 5276, Laboratoire de Géologie de Lyon : Terre, Planètes, Environnement, Université Claude Bernard Lyon 1, 27-43 Boulevard du 11 novembre 1918, 69622 Villeurbanne Cedex, France

\begin{abstract}
Upper Triassic reefs from the Panthalassa Ocean have been understudied in comparison to their Tethyan counterparts and are therefore pivotal to understanding the global reef evolution during
\end{abstract}


the Late Triassic. To fill this gap, Upper Triassic reef limestone from ten localities of the Sambosan Accretionary Complex at Shikoku Island (Japan) have been investigated. Biotic assemblages, quantitative microfacies analysis, and integrated biostratigraphy allow us to characterize two types of reefs, those attributed to the Ladinian?-Early Carnian and those attributed to the Late Carnian-Rhaetian?. At the regional scale, our data refine the biostratigraphic framework of the Upper Triassic Sambosan limestone. At the global scale, multivariate analyses support a strong paleobiogeographic affinity of the Western Panthalassa reef biota with those of the South Tethys Ocean during the Ladinian-Carnian and NorianRhaetian. Additionally, they indicate connections with East Panthalassa reefs during the Norian-Rhaetian.

Key words: Upper Triassic; Reef; Sambosan Accretionary Complex; Japan; Panthalassa; Biostratigraphy; Multivariate analyses

\section{Introduction}

Reefs are typically considered as high-biodiversity ecosystems that are extremely sensitive to environmental changes. Fossil reefs therefore constitute important records of marine environment evolution during geological times. The Late Triassic is a period of important reef development (Stanley, 1988; Flügel, 1981, 2002; Bernecker, 2005; Kiessling, 2010; Martindale et al., 2015). This development led to significant carbonate production worldwide and contributed to the expansion of carbonate platforms during the Late Triassic. During the Triassic, reef ecosystems experienced several changes with regards to their distributional patterns, paleogeographic settings, taxonomic composition, and biodiversity (Flügel, 2002; 
Bernecker, 2005). Reef evolution during the Triassic is typically viewed as a three step process, starting with Lower Triassic microbial-dominated reefs, followed by Anisian to Carnian and Norian to Rhaetian metazoan-dominated reefs (Stanley, 1988; Flügel, 2002). After the endPermian crisis, during the Early Triassic, bioconstructed deposits are dominated by microbial buildups (but see examples of metazoan-rich Lower Triassic reefs in Brayard et al., 2011; Marenco et al., 2012; Vennin et al., 2015). Reef recovery occurred largely in Western Tethys and South China during the Anisian (e.g., Payne et al., 2006) and was followed by a reef proliferation during the Ladinian-Early Carnian. Important changes in reef taxonomic composition occurred during the Late Carnian-Early Norian turnover (Flügel, 2002; Martindale et al. 2013). During the Norian-Rhaetian, reef ecosystems reached their maximum latitudinal distribution and highest biodiversity before experiencing a significant crisis at the end of the Triassic (Flügel, 2002). This global reef evolutionary trend is particularly well documented in the Tethys Ocean. However, Upper Triassic reefs of the Panthalassa Ocean have received less attention so far. Because most of the pre-Jurassic oceanic crust has been subducted, the study of the Triassic sediments from Panthalassa is primarily based on the remains of former oceanic islands and volcanic arcs preserved in circum-Pacific accretionary complexes and terranes. Panthalassic reefs are reported in allochthonous terranes in the American Cordillera (e.g., Stikinia, Reid and Ginsburg, 1986; Wallowa, Stanley and Senowbari-Daryan, 1986; Antimonio, Stanley et al., 1994; see also the review by Martindale et al., 2015) and in the Western Pacific archipelagos (Philippines, Flügel and Kiessling, 2000; Japan, Kanmera, 1969; Onoue and Stanley, 2008; Chablais et al., 2010). These Panthalassic reefs have been the focus of several sedimentological and paleoecological investigations in the recent decades (e.g., Onoue and Stanley, 2008; Chablais et al., 2010b; Martindale et al., 2012).

To improve our understanding of reef evolution in Panthalassa during the Late Triassic, we investigated reef limestone from the Sambosan Accretionary Complex (SAC) in Shikoku 
Island, Southwest Japan (Fig. 1a, b). The terrigenous-free limestone units of the SAC are interpreted as being the remains of shallow water atoll-type carbonates deposited on top of Panthalassic seamounts during the Late Triassic that accreted to the Asian margin during the Late Jurassic-Early Cretaceous (Kanmera, 1969; Onoue and Sano, 2007; Chablais et al., 2010a). Occurrences of reef facies and fauna were mentioned in the earliest studies of the Sambosan limestone (Kobayashi, 1931; Kanmera, 1964; 1969). Corals, in particular, have been reported from Kyushu (Kanmera, 1964; Stanley and Onoue, 2015), Shikoku (Okuda et al., 2005; Stanley and Onoue, 2015), and Kii Peninsula (Yamato Omine Research Group, 1976; Okuda and Yamagiwa, 1978; Okuda, 2006). Several former studies described microfacies and the biotic composition of the reef limestone in the SAC of Kuyshu and Shikoku Islands (Kanmera, 1969; Onoue and Stanley, 2008; Chablais et al., 2010b; Senowbari-Daryan et al., 2012) however, the authors focused on single reef localities. In this paper we describe ten reef localities along the SAC of Shikoku Island and provide the detailed biotic contents and quantitative assessment of the reef components for nine of them. Special focus is given to the paleoecology of the reef environment, especially on the biotic associations between framebuilders, microencrusters, and microbialites. Quantitative data significantly enhance our understanding of ancient reef ecosystems and allow us to reliably discriminate between different types of reefs. Our results are especially relevant when compared with similar quantitative analyses performed on coeval reef settings (e.g., Martindale et al., 2012, 2013a). Comparisons with coeval reefs in the Tethys and Panthalassa oceans provide data and constraints on the paleobiogeography of Upper Triassic reef biota that are pivotal to improving Late Triassic paleogeography reconstructions (Chablais et al., 2011; Martindale et al., 2015). Therefore, the objectives of this paper are (1) to report the occurrence of reef limestone from new localities in central and eastern Shikoku Island; (2) to quantitatively describe the biotic composition and reef structure of both new and previously studied reef localities of the SAC; 
(3) to provide biostratigraphic constrains on reef evolution in the Western Panthalassa; (4) to correlate and quantitatively compare the reefs from the SAC with their counterparts in the Tethys and Panthalassa oceans; and (5) to discuss the paleobiogeographic affinity of the reef biota of the SAC.

In this study we follow the reef definition by Riding (2002) in which all "calcareous deposits created by essentially in-place sessile organisms" are considered to be reef. This structural definition does not include any size or hydrodynamic requirement (e.g., elevation above the sea floor, resistance to waves). This definition particularly fits to our case study because, in the SAC, reef facies are often not identified in the field. The lack of stratigraphic successions and the strong recrystallization make reef facies recognizable only in thin sections. Additionally, because the limestone crops out as isolated massive units, criteria such as topographic elevation above the seafloor are not identifiable. As a consequence, several microfacies criteria are used in this study to identify true bioconstructed reef limestone. First, a significant amount of reef builder organisms (e.g., sponges, corals) must be present in the sample for it to be considered reef limestone. Ideally, the reef builders must be in-place, but it is often difficult to assess this criterion in thin sections. Moreover, in both modern and ancient reefs, broken and more or less reworked reef components are common, especially at the reef crest (Fagerstrom and Weidlich 2005; Martindale et al., 2013a). Second, the presence of microbial crusts and sessile organisms binding the reef builders together particularly helps to identify reef limestone. These binders usually represent an important part of the reef and highlight the reef framework, making it more recognizable especially when reef builders are recrystallized. Third, reef builders and binders typically define cavities that are filled with thick isopachous cement. Even if they are not totally restricted to reef facies, these cavities represent a valuable clue in identifying reef limestone because, along with builders and binders, they prove the presence of a reef framework. These three criteria allow us to reliably recognize reef limestone even with poorly preserved material. 
In other studies dealing with Upper Triassic reefs, several facies that do not completely fulfill these three criteria are sometimes included in reef limestone sensu lato (e.g., Wurm, 1982; Martindale et al., 2013a). These studies are based on more or less continuous limestone exposure where clear reef zonations can be established. For example, the relation between the fore-reef rudstone and the clearly bioconstructed part of a reef (reef core) could be determined in such preserved settings. In the SAC, such peri-reefal facies were also observed but the link with the bioconstructed facies remains hypothetical. In this study, when some facies did not fully meet the aforementioned criteria, they were excluded from the analyses. These excluded facies will be part of a separate facies analysis (Peybernes et al., ongoing work) focused on the different depositional settings that characterize the SAC build-up(s).

\section{Geological setting}

The Sambosan Accretionary Complex (SAC) is a narrow belt of the Outer Zone of Southwest Japan that can be followed from the Ryukyu Islands to the Kanto Mountains (Honshu) (Matsuoka, 1992; Onoue and Sano, 2007) (Fig 1a). The Butsuzo Tectonic Line (BTL) represents the boundary between the SAC and the Shimanto Accretionary Complex to the south. Typical lithologies of the SAC are basaltic rocks, shallow water limestone, limestone breccia and bedded chert. The basaltic rocks are geochemically referred to as oceanic island basalt of hotspot origin (Ogawa and Taniguchi, 1989; Ishizuka et al., 2003; Onoue et al., 2004; Safonova et al., 2015). The predominance of normal hotspot type oceanic island basalts implies that the basalts were erupted to form a seamount by an intraplate volcanism that occurred in a midoceanic realm (Onoue et al., 2004). The shallow-water limestone, limestone breccia, and bedded chert are interpreted to be the sediments at the top of a mid-oceanic seamount, its upper flank, and adjacent ocean floor, respectively (Onoue and Sano, 2007). 
Biostratigraphic markers (i.e., conodonts, foraminifers, sponges, microproblematica and corals) reported from the Sambosan limestone indicate that the deposition of shallow water carbonates ranges from the Ladinian?-Carnian to the Rhaetian (Onoue and Sano, 2007; Chablais et al. 2011; Peybernes et al., 2015). Based on conodont occurrence (Metapolygnathus nodosus) in inter-pillow lava limestone from Kyushu Island, the age of the eruption of the seamount(s) was estimated to be late Upper Carnian (Onoue and Sano, 2007). Nevertheless, Ladinian?-Lower Carnian reef biota reported from Shikoku suggests an earlier initiation for the carbonate sedimentation (Peybernes et al., 2015).

In the SAC, reef limestone units primarily outcrop either (1) as limestone clasts that are embedded in a volcaniclastic matrix (VCM) or (2) as massive limestone slabs (Fig. 2). The limestone clasts are a few centimeters to a few decimeters in diameter and form a breccia with a volcaniclastic matrix and basaltic clasts (VCM breccia). The massive limestone slabs are tens of meters to kilometers in size. The VCM breccia are typically interpreted as debris flow and debris avalanche deposits on the flank of a mid-oceanic seamount prior to the accretion at the trench (Onoue and Sano, 2007; Chablais et al., 2010a), whereas the massive limestone slabs probably resulted from the dismantling of the seamount in the trench and/or in the accretionary wedge during the accretion-subduction processes. The breccia units are often in close vicinity to massive limestone slabs or even in fault contact with them (Fig. 2a). In such cases (i.e., Mt. Sambosan and Mt. Ishidate), limestone clasts of the VCM breccia and the massive limestone slabs are treated separately as two distinct localities (e.g., Loc. 4 Mt. Sambosan 1 and Loc. 5 Mt. Sambosan 2).

\section{Studied areas}

Between 2012 and 2013, the Sambosan limestone localities in central and eastern Shikoku were systematically investigated. Material for this study comes from 10 localities where reef 
limestone has been collected, most often associated with other limestone facies that are not considered in this paper. These localities are described below and key information is summarized in Table 1.

\section{Tsuno area}

The Tsuno area includes three localities: Loc. 1 Inaba cave, Loc. 2 Tsuno windmill, and Loc. 3 Tsuno (Fig. 1c). At Loc. 1 Inaba cave, reef limestone occurred as karstified massive limestone slabs up to hundreds of meters in lateral extent and as limestone blocks along the nearby Shimanto River. The Inaba cave has been investigated by Onoue et al. (2009) and Chablais et al. (2010b) who attributed these limestone slabs to the Norian-Rhaetian based on the reef biota. Some samples described by these authors are used for point counting and thin section mapping. Loc. 2 Tsuno windmill is a new locality on the mountain crest northwest of Tsuno town where karstified massive limestone slabs crop out. In contrast, reef limestone blocks occurred in a VCM megabreccia at Loc. 3 Tsuno. This locality is described in more detail by Peybernes et al. (2015) who attributed these blocks to the Ladinian?-Carnian.

\section{Mount Sambosan area}

The Mount Sambosan area corresponds to the Sambosan type locality (Yamato Omine Research Group, 1981) and has been studied by several authors including Kobayashi (1931), Yamato Omine Research Group (1981), Okuda et al. (2005), Chablais (2010), and Peybernes et al. (2015). There, reefal limestones crop out as massive limestone slabs (Loc. 4 Mt. Sambosan 1) and as clasts in matrix-supported VCM breccia (Loc. 5 Mt. Sambosan 2) (Fig. 1d). The massive limestone slab is in fault contact with the breccia unit (Fig. 2). According to Stanley and Onoue (2015), at Mt. Sambosan (Loc. 4), the massive white limestone slab is composed of clastsupported polymict limestone breccia that represent talus deposits. In this study we only focus 
on the reefal parts of the Sambosan type locality, as described in the introduction (see section 1). The Yamato Omine Research Group (1981) reported, but did not illustrate, conodonts from several outcrops in the Mt. Sambosan area: Epigondolella nodosa and Gondolella polygnathiformis (Carnian), Epigondolella postera and Epigondolella abnetis (Norian), and Misikella hernsteini and Misikella posthernsteini (Rhaetian). In particular, they mentioned the Norian conodonts (Epigondolella postera and Epigondolella abnetis) from the massive limestone slab unit at Loc. 4 Mt. Sambosan 1. Clasts in VCM breccia have been attributed to the Ladinian?-Carnian based on sponge, microproblematica, foraminifer, and coral occurrences (Okuda et al., 2005; Peybernes et al., 2015).

\section{Befu/Kito area}

This area includes four localities: Loc. 6 Befu, Loc. 7 Mt. Ishidate 1, Loc. 8 Mt. Ishidate 2, and Loc. 9 Konose Kyo (Fig. 1e). At Loc. 6 Befu the limestone units are too poorly preserved for relevant reef facies analysis but yield an interesting conodont fauna. Thus, the reef facies of this locality are not studied in details but the conodont fauna is described in section 5.1. The conodonts have been found in reefal blocks that most likely detached from the nearby cliff. Loc. $7 \mathrm{Mt}$. Ishidate 1 and Loc. $8 \mathrm{Mt}$. Ishidate 2 are two localities along the trail leading to the Mt. Ishidate summit. The first corresponds to massive reef limestone slabs and the second to Ladinian?-Early Carnian reef limestone clasts embedded in a VCM matrix (Peybernes et al., 2015). Loc. 9 Konose Kyo is situated on a mountain crest in Konose Valley where reef limestone clasts occurred in a VCM matrix. A few additional samples, previously collected along the road close to Loc. 9 Konose Kyo by Chablais (2010) have also been used. Loc. 9 Konose Kyo and Loc. 8 Ishidate 2 are further described in Peybernes et al. (2015).

\section{Wajiki area}


The locality in Wajiki area (Loc. 10 Road 28) is situated in a quarry above the Road 28 (Fig. 1f) and is described here for the first time. Reef limestone clasts crop out, along with basaltic clasts and limestone clasts of other facies, in a VCM breccia. This unit is in tectonic contact with recrystallized massive limestone slabs. This mode of occurrence is very similar to Loc. 5 Mt. Sambosan 2.

\section{Material and methods}

For this study, 260 thin sections were prepared $(2.3 \times 3.5 \mathrm{~cm}$ and $4.7 \times 3.5 \mathrm{~cm})$, scanned with a high-resolution film scanner (Nikon CoolScan 4000 ED) and observed in transmitted light under an optical microscope (Zeiss Axioskop). For all samples, microfacies were described and reef fauna determined (see Supplementary material S1). Forty-eight well-preserved samples were selected for point counting analysis. Thin sections showing only a specific reef organism and used for taxonomic purposes were not selected for point counting to avoid overestimation of a single biotic group.

To establish robust biostratigraphic ages, limestone samples were dissolved in $10 \%$ acetic acid for conodont extraction. After sieving and picking, samples were mounted on conductive aluminum support. An ultra-thin coating (ca. $10 \mathrm{~nm}$ ) of gold was then deposited on the samples by low vacuum sputter coating prior to imaging with a Jeol JSM 7001F Scanning Electron Microscope (Department of Earth Sciences, University of Geneva, Switzerland).

Point counting was used to quantitatively assess the relative abundances of reef components. Following Flügel (2004), 300 points were randomly counted (grain bulk method) on scanned thin sections by using an image analysis software (JMicrovision). Recursive and random grids were both tested and results were similar. The random grid fit better with the studied thin sections because the recursive grid could trigger some bias if counted points systematically follow major fractures or other diagenetic features. Nevertheless, even if a random grid is 
preferred, our method provides similar results to those commonly used in other studies (e.g., Blendinger, 1994; Olivier et al., 2004; Martindale et al., 2010, 2013a, b) and, therefore the results can be compared.

Hierarchical cluster analysis (hCA) has been applied to quantitatively assess the taxonomic similarities between reef communities. To date, these methods have rarely been used for paleoecological and paleobiogeographical investigations of Late Triassic reef biota (Schäfer, 1979; Stanley, 1979; Stanton and Flügel, 1987; Yarnell, 2000; Rosenblatt, 2010; SanchezBeristain, 2010). We performed cluster analyses on two different datasets. The first one records the occurrence of 56 species or higher rank taxa of calcareous sponges, microproblematica, and foraminifers reported from the 10 studied localities of the SAC (see section 5.3). The second dataset is a taxonomically homogenized compilation of the occurrence of 201 genera of calcareous sponges (117 genera), microproblematica (17 genera) and foraminifers (67 genera) from 18 geographical areas ("region” sensu Veron, 1995 or "domain” sensu Flügel, 2002) in the Tethys and Panthalassa oceans. Calcareous sponges, microproblematica, and foraminifers were selected for the cluster analyses because: (1) they are important reef builders and dwellers that accurately represent the Triassic reef communities; (2) they show high diversity that allow them to be used for multivariate analysis; and (3) they are rather easy to identify at the generic level (compared to corals or algae, for example) and are therefore often reliably reported in the literature. These three groups can be included in the same analysis because they share similar ecologies (juvenile planktonic stage and adult benthic stage, either sessile or with little displacement). Major revisions in coral taxonomy (e.g., Roniewicz, 1989) since the original publications make the comparisons of corals between reef sites difficult (Martindale et al., 2015); therefore, they are not included in this study.

Hierarchical cluster analyses (hCA) were performed using PAST software (v. 3.05) with a UPGMA algorithm and Dice (= Sørensen) coefficient of taxonomic similarity: $S_{\text {Dice }}=\frac{2 C}{A+B}$, 
where $A$ and $B$ are the number of taxa in samples $\mathrm{A}$ and $\mathrm{B}$, and $C$ is the number of taxa shared by A and B. The Dice coefficient was selected because of the double weight given to shared presences and thus relative underweighting of absences and unique occurrences that might be due to sampling bias and does not reflect real differences in taxa distribution (Brayard et al., 2007). This makes the Dice coefficient highly reliable for biogeographical analyses even when comparing biogeographic areas with unequal sampling effort because it emphasizes similarity rather than differences among sampling units (Cheetam and Hazel, 1969; Garcia-Bellido and Rodriguez, 2005). In particular, The Dice coefficient is moderately affected by differences in taxonomic richness between the studied localities (Shi, 1993; Arias, 2006). The Dice coefficient has been commonly used in other paleocological and paleobiogeographical studies (e.g., Aberhan, 1998, 2001; Garcia-Bellido and Rodriguez, 2005; Arias, 2006; Hopkin, 2009; Niu et al., 2011; Brayard and Escarguel, 2013; Brayard et al., 2015). The statistical significance of the taxonomic dissimilarity between the obtained clusters was tested through Analysis of Similarity (ANOSIM) and the relative contribution of each taxon to the overall inter-cluster compositional dissimilarity was evaluated through SIMPER analysis, using the Dice coefficient for each analysis (Clarke, 1993).

Even with the Dice coefficient of similarity, localities with close generic richness may cluster together, making it difficult to determine whether this grouping is due to genuine biogeographic reasons or to a taxonomic richness-induced bias unrelated with the biogeographical history of the studied localities (Smith, 1988; Niu et al., 2011). In other words, it is worth knowing if the clusters identified through hCA do reflect biogeographically controlled, richness-free similarities in taxonomic composition or similarities in taxonomic richness that may not be directly explained by the biogeographical history. To untangle the potential effect of taxonomic richness and composition on the cluster analyses we first converted the Dice similarity matrix $\left(\mathbf{S}_{\text {dice}}\right)$ into a dissimilarity matrix $\left(\mathbf{D}_{\text {dice }}=1-S_{\text {dice }}\right)$. Baselga $(2010,2012)$ showed that $\mathbf{D}_{\text {dice }}$ can be 
additively decomposed into two independent components: a compositional dissimilarity matrix known as the Simpson dissimilarity matrix $\left(\mathbf{D}_{\text {Simp }}\right.$ with $D_{\text {Simp }}=\frac{C}{\min (A, B)} ;$ Simpson, 1960), and a richness dissimilarity matrix referred to as the Nestedness dissimilarity matrix $\left(\mathbf{D}_{\text {nest }}\right)$ where: $D_{\text {Dice }}=D_{\text {Simp }}+D_{\text {Nest }} \rightarrow D_{\text {Nest }}=D_{\text {Dice }}-D_{\text {Simp. }}$. Finally, a comparison of $\mathbf{D}_{\text {dice }}$ ("total" taxonomical dissimilarity), $\mathbf{D}_{\text {Simp }}$ (compositional dissimilarity), and $\mathbf{D}_{\text {nest }}$ (richness dissimilarity), using onetailed Mantel tests (9 999 permutations), allows the separate effect of richness (Nestedness) and compositional (Simpson) dissimilarities on the "total" (Dice) taxonomic dissimilarity to be assessed.

\section{Results}

The main reef components in the Sambosan limestones are recrystallized sponges, microbialites, and microproblematica. Consequently, most of the analyzed samples can be described as sponge-microbialite boundstones. To improve the accuracy of description, the determination of minor reef components and relative abundances are required. Accordingly, an inventory of reef components, point-counting results, and thin section mapping are presented in the following sections. Dating of Upper Triassic reef limestone is typically based on the association of reef builders (e.g., Bernecker, 2005). However, biotic assemblages alone can sometimes be misleading (Martindale et al., 2013b) and additional independent age indicators should be used to provide an accurate and more reliable dating. Therefore, conodont extraction has been performed on numerous samples to provide independent data for reef dating.

\subsection{Conodonts}

Thirty four samples of shallow water limestone were processed for conodont extraction. Microfacies analysis was also performed on the same samples. Age-relevant conodonts were found at Loc. 1 Inaba, Loc. 4 Mt. Sambosan 1 and Loc. 6 Befu (Fig. 3). The determination was 
by M. Orchard and the taxonomy follows Orchard (2014). Parvigondolella? sp. occurs at Loc.1 Inaba (CP104) in massive limestone slabs and indicates a Late Norian-Rhaetian age. At Loc. 4 Mt. Sambosan 1, conodonts were found in blocks situated between the well-exposed massive limestone slab and the limestone VCM breccia (Fig. 2). Microfacies and biotic content show that these blocks are related to the massive limestone slab. Here the conodont fauna consists of ?Quadralella sp. (CP213-9), Primatella stanleyi (CP213-4) and Krassodontus roberti alpha morphotype (CP214-5). In the Black Bear Ridge section, Primatella stanleyi is present in the angusta-dylani Subzone through the asymmetrica-Norigondolella sp. Subzone of the primitia Zone (Orchard, 2014). Additionally, representatives of this species were illustrated from the Lower Norian of Feuerkogel (Krystyn, 1973). The association with Krassodontus roberti alpha morphotype, which is common in the sagittale-beattyi Subzone through the acuminataprominens Subzone of the primitia Zone, indicates a Late Carnian age for this massive limestone slab. The conodont fauna at Loc. 6 Befu is composed of Quadralella sp. (CP59-1), Carnepigondolella samueli (CP59-5), Carnepigondolella cf. spatulata (CP59-4) and Quadralella lobata (CP59-9). Carnepigondolella samueli is the index to the Upper Carnian samueli Zone (Orchard, 2014). The co-occurrence of Carnepigondolella cf. spatulata (common in the spenceri Subzone of the samueli Zone) and Quadralella lobata (common from the base of the Black Bear Ridge section in British Columbia, Canada, through the zoae Subzone of the samueli Zone; see Orchard, 2014) confirms the attribution of the massive limestone slabs at Loc. 6 Befu to the Upper Carnian. Biostratigraphic implications of these conodont assemblages are discussed in section 6.3.

\subsection{Reef biota}

Reef limestone of the SAC contains a comprehensive reef biota including scleractinian corals, calcareous sponges, red algae, mollusks, brachiopods, echinoderms, worm tubes, foraminifers, 
and microproblematica. Reef taxa from the SAC at Shikoku Island are reported below and are illustrated in Figs. 4 and 5 (see also Chablais et al. 2010 and Peybernes et al., 2015). We also mention some sponges, foraminifers, and microproblematica reported from the Koguchi locality at Kyushu Island (Senowbari-Daryan et al. 2012) because we included them in the cluster analyses.

Corals are primarily represented by phaceloids and thamnasterioid growth forms. Despite the numerous descriptions in the literature (Okuda, 2006; Okuda et al., 2005; Stanley and Onoue, 2015) they are relatively rare in the SAC.

Calcareous sponges include Sphinctozoan, Inozoan, Chaetetids, Spongiomorphids, and Disjectoporids. Sphinctozoan (segmented sponges) are the most frequent. They are represented by Celyphia? minima (Fig. 4l), Celyphia zoldana, Cryptocoelia sp., Cryptocoelia zitteli, Colospongia sp., Discosiphonella sp., Jablonskia andrusovi, Paradeningeria sp., Permocorynella sp., Solenolmia manon, Stylothalamia dehmi, Uvanella irregularis, Uvanella ? lamellata, and Zardinia perisulcata (Chablais et al., 2010; Senowbari-Daryan et al., 2012; Peybernes et al., 2015). Inozoan are unsegmented sponges that are often difficult to distinguish from Sphinctozoan. Because longitudinal sections are required for reliable attribution to this taxon, only a few specimens can be tentatively attributed to Inozoan; Chablais et al. (2010) reported Peronidella sp. at Loc. 1 Inaba. Chaetetids are abundant at Loc. 1 Inaba and Loc. 4 Mt. Sambosan 1 (Fig. 5g). Disjectoporids and Spongiomorphids are less frequent and are represented by Disjectopora sp. and Spongiomorpha sp. (Chablais et al., 2010). The encrusting sponge Murania kazmierczaki is present at Loc. 3 Tsuno (Peybernes et al., 2015).

Foraminifers, especially porcelaneous taxa, are frequent. It is widely accepted that Upper Triassic carbonates recorded the appearance and expansion of many new species of porcelaneous reefal foraminifers (Chablais et al., 2011). The reef environment undoubtedly provides numerous protected ecologic niches colonized by these organisms (Chablais et al., 
2011), explaining the coeval diversification of porcelaneous reefal foraminifers related to the reef expansion during the Late Triassic. For the purpose of the paper we divided foraminifer assemblages into categories according to their ecological strategy rather than their systematic position.

Ophtalmidids and other porcelaneous foraminifers are frequent in the interstitial sediment between the reef frameworks. Among them, Cucurbita infundibuliforme (Fig. 4e) and Hydrania dulloi occur in cement-rich microbialite (often in association with the sponges Zardinia sp. and Cryptocoelia zitteli), whereas Galeanella sp. (Fig. 4b) occurs preferentially in grainstonepackstone sediment that infills the interstices between sponges.

Encrusting foraminifers are sessile forms that lived attached to framebuilders. They are frequent in reef limestone of the SAC. Common species are Flaschkofelia anisica (Fig. 4f), Alpinophragmnium perforatum, Planiinvoluta carinata (Fig. 4c), and Tolypammina gregaria. Koskinobullina socialis and Nubecularids occasionally occur (Peybernes et al., 2015). No preference for a particular type of substrate has been observed for any of them.

Cosmopolitan forms are ecologically tolerant species that are found in reef facies but they are also present in other settings such as back-reefs and lagoons. This group is primarily represented by “Trochammina” sp., Endotriada sp., Duostominids (Fig. 4a), and Nodosarids.

Bivalve shell fragments, gastropods, echinoderms, and brachiopods are common in interstitial reef sediment. Echinoderms are represented by crinoid sticks, urchin spines, and holothurian sclerites. Free-living brachiopods are common (Fig. 5a) as well as sessile brachiopods (Gosaukammerella eomesozoica, Fig. 5b), which attach to sponges and corals.

Microproblematica are organisms of uncertain systematic affinity. Tubiphytes (Fig. 41) and similar organisms represent one of the most abundant groups of microproblematica in Upper Triassic reefs especially in the Carnian (Senowbari-Daryan, 2013). Members of this group include several growth forms ranging from fragile micritic tubes (e.g., Plexoramea gracilis) to 
thick organisms that are able to build reef frameworks (Tubiphytes obscurus). Several other encrusting and free-living microproblematica of minor importance are present. Among them, Baccanella floriformis (Fig. 4g), Actinotubella gusici (Fig. 4h), Ladinella porata (Fig. 4i), Radiomura cautica (Fig. 4j) and Microtubus communis (Fig. 4k) are the most frequent.

Attached or free-living worm tubes that are composed of agglutinated clotted micrite (Terebella sp., Fig. 5d) are common. Serpulids tubes have light calcitic walls and are relatively rare in the reef limestone of the SAC. They occur either as single encrusting tubes or as colony-like bundles of tubes (Filograna sp., Fig 5e-f).

Red algae are important reef constituents. Solenoporacean are present in reef limestone of the SAC but are often poorly preserved. Parachaetetes sp., Solenopora sp., and Dendronella articulata have been reported (Peybernes et al., 2015). Dasycladacean are virtually absent. Cyanobacteria sheaths (Girvanella sp.) are common, especially at Loc. 3 Tsuno. While common in other facies, calcimicrobes such as Garwoodia or Cayeuxia are rare or absent in reef facies.

\subsection{Biotic associations}

Biotic associations provide valuable insight into the ecological structure of the reef ecosystem and also provide important biostratigraphic data. The distribution of identified taxa in the reef limestone of the SAC at Shikoku is summarized in Supplementary material S1. Data are compiled from Chablais et al. (2010) and Peybernes et al. (2015, this study). Coral fauna of the SAC were recently reviewed by Stanley and Onoue (2015) and, therefore, they are not included in this paper.

Hierarchical cluster analyses (hCA) allow us to quantitatively assess the taxonomic similarities between the reef communities from different localities. The distribution of sponges, foraminifers, and microproblematica was summarized in a presence/absence matrix, which is used for the cluster analysis (UPGMA with the Dice coefficient of similarity). Other taxa, such 
as algae, were not selected because of their low diversity and scattered distribution among the samples. Data from the reef limestone clasts of the Koguchi locality at Kyushu (SenowbariDaryan et al., 2012) are included in the analysis.

Cluster analysis based on taxa occurrences clearly shows that the reef localities at Shikoku are divided into two main groups (Fig. 6). The first cluster, termed Reef Type 1, includes five localities: Loc. 3 Tsuno, Loc. 5 Mt. Sambosan 2, Loc. 7 Mt. Ishidate 2, Loc. 8 Konose Kyo and the Koguchi locality. In all these localities, limestone characteristically crops out as clasts embedded in VCM. The second cluster, termed Reef Type 2, is comprised of Loc. 1 Inaba, Loc. 2 Tsuno windmill, Loc. 4 Mt. Sambosan 1, Loc. 7 Mt. Ishidate 1 and Loc. 10 Road 28. These localities are characterized by outcrops of massive limestone slabs, except at Loc. 10 Road 28 where reef limestone crops out in VCM breccia. Similar results are observed with other clustering methods (e.g., neighbor-joining) and coefficients of similarity (e.g., Jaccard, Simpson). The ANOSIM test strongly supports the differences between Reef Type 1 and Reef Type $2(\mathrm{p}=0.0078 * *)$.

In terms of the biotic association, characteristic taxa of the cluster Reef Type 1 are Zardinia perisulcata, Uvanella irregularis, Cryptocoelia zitelli, Celyphia spp., Cucurbita infundibuliforme, Tubiphytes sp., Plexoramea cerebriformis, Plexoramea gracilis and Ladinella porata. Uvanella? lamellata and Piallina spp., Hydrania dulloi and Trocholina cordevolica occasionally also occur in the localities of this cluster. The cluster Reef Type 2 is characterized by the abundance of Chaetetids, and the presence of Galeanella sp. and Microtubus communis. Decapoalina schaeferae, Alpinophragmium perforatum and Actinotubella gusici are subordinate taxa that are also present in the same localities.

SIMPER analysis reveals that the separation between the two main clusters is primarily driven by the occurrence of Tubiphytes sp. and Plexoramea gracilis in Reef Type 1 (contributing to $5.2 \%$ and $4.8 \%$ of the overall between-cluster taxonomical dissimilarity, respectively). 
Grouping patterns within each cluster are more difficult to interpret and may only reflect sampling heterogeneities among localities.

\subsection{Reef structures}

The reef structure is commonly divided into two main categories: the reef framework (primary and secondary framebuilders) and the interstitial reef sediments including sedimentary grains, microbialites and cements.

The reef framework constitutes the reef architecture and is composed of primary framebuilders (i.e., organisms whose carbonate skeletons form the reef structure) and secondary framebuilders that include binding microbial crusts and other encrusters. Secondary framebuilders are sessile organisms smaller than the primary framebuilders acting as a substrate for settlement. In the Sambosan reef limestone, primary framebuilders are represented by sponges, corals, Tubiphytes, and solenoporacean. Most of the sponges, corals and solenoporacean are strongly recrystallized. However, this recrystallization follows the main feature of the primary skeleton (i.e., sponge chambers, coral septa, solenoporacean cells). Each group can therefore be easily distinguished from the others. Rarely, sponges may encrust other organisms. To be consistent, all sponges are considered as primary framebuilders. Similarly, solenoporacean algae are sometimes only sediment contributors, but most of the solenoporacean specimens seem to remain in the erected life position and are encrusted; therefore, they act as primary framebuilders and are considered in this category. Colonial serpulid worm tubes (Filograna sp.) are also considered to be primary framebuilders. The Tubiphytes category includes all Tubiphytes-like organisms (i.e., Tubiphytes, Plexoramea) interpreted to be mainly in the life position and acting as framebuilders. Tubiphytes are often interpreted as encrusters in other studies (e.g., Martindale et al., 2013a), but in this study Tubiphytes is considered a framebuilder as there is no evidence of encrustation on other organisms in the SAC reef rocks. Moreover, 
they noticeably define cavities and sometimes act as a substrate for other organisms. Nevertheless, fragments of Plexoreamea cerebriformis and Plexoramea gracilis are counted as non-encrusting microproblematica (dwellers) and could be considered important sediment producers (Senowbari-Daryan, 2013). Secondary framebuilders are represented by encrusting organisms and microbial crusts. The encrusting organism group (also called epibiont) is primarily composed of sessile microproblematica (e.g. Radiomura cautica, Microtubus communis) but also of sessile foraminifers, serpulids, agglutinated worm tubes, and encrusting brachiopods (e.g., Gosaukammerella eomesozoica). Microbial crusts (formerly called spongiostromata) form a defined layer of more or less clotted and laminated micritic material, binding other framebuilders. They are often associated with encrusting organisms.

Interstitial reef sediment composed of skeletal and non-skeletal grains, microbialite, and cements fill the space between the framebuilders. Skeletal grains (i.e., reef dwellers) are represented by foraminifers, fragments of echinoderms, mollusks, brachiopods, and nonencrusting microproblematica (e.g., Plexoramea spp., Baccanella floriformis). Non-skeletal grains include peloids and ooids. Smaller peloids with a loose lining composed the peloidal and clotted micrite. Most of the ooids and spar-rimmed peloids are recrystallized and, along with peloids and dwellers, constitute a cement-rich grainstone facies. Microbialites are deposits controlled by benthic microbial communities (Burnes and Moore, 1987; Riding, 2000); in thin sections, they appear as micritic, peloidal, clotted and/or laminated textures. In the Sambosan reef limestone microbialites are primarily represented by peloidal and clotted micrite (thrombolite), and secondarily by a more or less laminated microbial crust (considered to be secondary framebuilders, see above). Peloidal and clotted micrite are composed of tiny peloids (10 to $40 \mu \mathrm{m}$ in diameter) that are more or less clustered and, occasionally, surrounded by a thin spar rim. This texture is also variously reported as automicrite (Wolf, 1965; Keim and Schalger, 1999), peloidal micrite (Russo et al., 1997), internal micrite (Reid et al., 1990), or 
peloidal cement (Flügel, 2004). Peloidal and clotted micrite is typically interpreted as being microbially induced precipitate (Chafetz, 1986; Reid, 1987). Conversely, denser micrite is considered to be depositional carbonate mud and is counted separately. Peloidal and clotted micrite occurs in reef cavities and is associated with various reef builders. Clotted peloidal micrite within framework cavities has commonly been linked to anaerobic bacteria (Tosti et al., 2014 and reference therein). In many cases, fenestrae are observed in the peloidal and clotted micrite. Peloidal and denser micrite may include small dwellers such as porcelaneous foraminifera and tiny bioclasts. Two types of cements fill the remaining space of the reef limestone. The first corresponds to granular to blocky cements that occupy the interstices between grains and infilled small fenestrae. This type of cement may be slightly overestimated in the point counting due to recrystallization processes. The second type of cement corresponds to tanned isopachous cements that cover voids and cavities within the reef framework. A secondary generation of blocky sparite fills the remaining porosity. These isopachous cements are often considered to be early cements resulting from efficient water pumping through the reef cavities (Riding, 2002). This type of cement is especially abundant at Loc. 5 Mt. Sambosan 2. Cements in fracture are not considered for the point counting.

The relative abundances of reef components were assessed using point counting. The mean values and associate 95\% "exact" Clopper-Pearson confidence intervals of the relative abundances of reef components for each locality are presented in Table 2. The relative importance of the reef framework versus the interstitial sediments is shown in Table 3. Additionally, the relative abundances of the main reef components are displayed in Fig. 7.

Loc. 3 Tsuno, Loc. 5 Mt. Sambosan 2, Loc. 8 Mt. Ishidate 2 and Loc. 9 Konose Kyo clearly show similar mean relative abundances of reef constituents (Tables 2 and 3; Fig. 7). They are characterized by high abundances of Tubiphytes and peloidal and clotted micrite. The reef framework represents a relatively low volume and does not exceed $33 \%$. Up to $80 \%$ of the rock 
volume is occupied by the interstitial sediment. These localities correspond to Reef Type 1, as defined by our cluster analysis (see section 5.3). Loc. 1 Inaba, Loc. 2 Tsuno windmill, Loc. 4 Mt. Sambosan 1 and Loc. 7 Mt. Ishidate 1 present some similarities regarding the frequency of reef components. They are characterized by the abundance of sponges and a significant reef framework (40-60\% of the rock volume) and correspond to Reef Type 2, as defined by our cluster analysis (see section 5.3). The reef structure pattern at Loc. 10 Road 28 is less clear. The reef framework volume is relatively low (approximately 30\%) but sponges are comparatively abundant (21\%) and Tubiphytes are rare.

Overall, the relative abundances of reef components allow us to distinguish between two types of reefs that are consistent with those revealed by the cluster analysis based on biotic associations. These two independent and concordant analyses emphasize the distinction that can be drawn between two types of reefs in the SAC at Shikoku.

To illustrate the two types of reef, thin section mapping of characteristic samples are shown in Fig. 8. The reef framework of Reef Type 1 is composed of sponges and Tubiphytes that define voids and cavities filled with isopachous cements (Fig. 8a, b). Microproblematica and both clotted and peloidal micrite are abundant. Alternatively, the reef framework of Reef Type 2 is composed of Chaetetids and other sponges (Fig. 8c, d). Microbial crusts associated with Microtubus communis are frequent and the interstitial reef sediment is composed of peloidbioclast-ooids packstone-grainstone.

\subsection{Comparison with reef biota from the Tethys and Panthalassa}

Quantitative analysis based on the taxonomic composition of selected Upper Triassic reefs from the Tethys and Panthalassa oceans were used to assess the biostratigraphic and biogeographic affinities of the reef fauna from the SAC. Reef taxa occurrences from the Panthalassa and Tethys oceans were compiled from the literature to be compared with our data (see Table 4). 
The compilation is restricted to time intervals and areas where reef fauna have been thoroughly investigated and where sponges, microproblematica and reef-dwelling foraminifer assemblages are described in detail. These areas correspond either to one extensively studied locality or to a composite record of several localities closely related to each other in time and space. Two time intervals are considered: Ladinian-Carnian and Norian-Rhaetian. For some areas, Upper Anisian reef fauna were added to the Ladinian-Carnian interval. The time slices used in this analysis correspond to well-established reef fauna associations, separated by the Carnian/Norian turnover (Flügel, 2002). The occurrences of sponges, microproblematica and foraminifers from the literature were attributed to 16 areas ( 8 for the Ladinian-Carnian and 8 for the Norian-Rhaetian) according to their paleogeographical location in the Late Triassic. Regarding the data from Japan, reef biota corresponding to the two main clusters of Fig. 6 were included in the analysis as Japan Reef Type 1 and Japan Reef Type 2. For each reef area, the generic richness and references are summarized in Table 4. The table of taxonomic occurrence used for the cluster analysis is presented in Supplementary material S2. Taxon occurrences have been compiled at the species level but are treated at the generic level to minimize the discrepancies in taxa identification between authors. Indeed, using the genus level avoids most of the systematic bias that essentially resides at the species level (Brayard et al., 2007). Paleobiogeographic studies are often based on genus-level analyses (e.g., Belasky et al., 2002; Niu et al., 2011). Sponge and foraminifer genera were updated when necessary, according to recent literature (e.g., Senowbari-Daryan and Garcia-Bellido, 2002; Gale et al., 2012). Because they are not often identified at the genus level in the literature, Duostominids and Nodosarids are treated at the family level.

Total generic richness is higher on the western and northern Tethys margin than on the southern Tethys margin and in the Panthalassa (Fig. 9, Table 4). The same pattern is observed when sponges, foraminifers, and microproblematica are considered separately. The variation of 
generic richness in areas represented at both time intervals (Ladinian-Carnian and NorianRhaetian) shed light on the evolution of reef diversity during the Late Triassic. Generic richness is generally higher in the Norian-Rhaetian than in the Ladinian-Carnian except for Japanese reefs where the generic richness remains stable, and for Slovenian reefs, where it decreases. The increased reef diversity during the Norian-Rhaetian is well-known (Flügel, 2002). However the stable pattern of reef diversity in Japan and its decrease in Slovenia, still require explanation.

Uniques are taxa characterized by a single occurrence in the dataset. They are not necessarily all genuine endemic taxa because they may also occur in reef localities that are not considered in this study. However, they provide information regarding the level of endemism of the taxonomic assemblages under scrutiny (Brayard et al., 2007). In our dataset, uniques represent approximately $32.8 \%$ of the genera (66/201). Uniques are predominantly sponge genera (41\% of the sponge genera and $23.9 \%$ of the total genera). Foraminifers include $25.4 \%$ of uniques (8.5\% of the total genera). Only $5.9 \%$ of Microproblematica genera are single occurrence taxa ( $0.5 \%$ of total genera). The Dolomites (Ladinian-Carnian), Sicily, Iran, and Turkey (NorianRhaetian) show the highest percentage of uniques $(13.5 \%, 21.3 \%, 18.8 \%$ and $14.6 \%$ respectively) that correspond primarily to sponge genera.

Hierarchical cluster analysis (based on the UPGMA algorithm with the Dice coefficient of similarity) was applied to the compiled dataset. On the one hand, the Mantel tests (see section 4) show a strong and highly significant positive correlation between the Dice ("total") and Simpson (compositional) dissimilarity matrices $(\mathrm{R}=0.7685 ; \mathrm{p} \leq 0.0001 * * *)$. On the other hand, the correlation between the Dice and the Nestedness (richness) dissimilarity matrices is not significant $(\mathrm{R}=-0.06244 ; \mathrm{p}=0.7423)$. Thus, clusters based on the Dice coefficient are not significantly affected by differences in taxonomic richness but reflect richness-free variations of taxonomic composition between the different localities of interest. 
The dendrogam resulting from the hCA identifies two main clusters (Fig. 10). The first one includes all Ladinian-Carnian reef fauna and the Japan Reef Type 1. The second cluster comprises all Norian-Rhaetian reef fauna and the Japan Reef Type 2. The ANOSIM strongly supports the validity of these two main groups $(\mathrm{p} \leq 0.0001)$. Therefore, the dendrogram reliably allows us to distinguish the Ladinian-Carnian reef faunas from the Norian-Rhaetian ones. Relationships within each main group are less straightforward but are, in general, consistent with the paleogeographic position of the reef localities (Fig. 11). Paleobiogeographic implications of these groupings are discussed below (see section 6.5).

SIMPER analysis assesses the contribution of each taxon to the two-cluster main structure identified by hCA. Accordingly, the Ladinian-Carnian cluster is primarily distinguished from the Norian-Rhaetian one by the genera Ladinella, Plexoramea, Zardinia, Jablonskya and Alpinothalamia. Conversely, the Norian-Rhaetian cluster is primarily distinguished from the Ladinian-Carnian one by Alpinophragmium, Decapoalina, Galeanella, Paradeningeria and Microtubus. Nevertheless, the contribution of each of these taxa to the overall among-cluster taxonomic dissimilarity is rather low $(\leq 2 \%$ in all cases $)$.

\section{Discussion}

\subsection{Preservation bias}

The preservation of microfacies differs between massive limestone slabs and limestone clasts in VCM breccia. As previously observed (Chablais et al., 2010a; Peybernes et al., 2015), limestone clasts and blocks of the VCM breccia are less recrystallized than the massive limestone slabs. This difference in preservation has a significant impact in species determination but does not significantly affect point counting results because the main 
categories of reef components are still recognizable. Therefore, reef limestone clasts and massive reef limestone slabs can be reliably compared using quantitative microfacies analysis.

\subsection{Types of Reef}

Framebuilders in the SAC are predominantly represented by calcareous sponges, small coral colonies and Tubiphytes that correspond to low-growing communities. These observations contrast with the high-growing communities (mainly phaceloid corals and coralline sponges) characterizing the Norian and Rhaetian Dachstein reefs in Western Tethys (e.g., Stanton and

Flügel, 1987; Bernecker et al., 1999; Flügel, 2002; Martindale et al., 2015). The reef builder growth forms and the abundance of interstitial sediments suggest that Upper Triassic reefs of the SAC did not stand high above the sea floor but were low relief reefs. Therefore, according to the abundance of interstitial sediments, they are better designated as reef mounds (Kiessling et al., 1999, Kiessling and Flügel, 2002).

Our field observations, microfacies analysis, biotic assemblages and point counting results allow us to discriminate between two main types of reefs in the reef limestone from the SAC. A first distinction, based on the lithology and previously observed at the Mt. Sambosan locality by Okuda et al. (2005), can be drawn between massive white limestone slabs and grey limestone clasts embedded in the volcaniclastic matrix (VCM breccia) (see sections 2 and 3).

A comparison of the taxonomic content and biotic assemblages also shows clear differences between massive limestone slabs and limestone clasts (see section 5.3). Significant differences in the biotic composition between the lithologically different types of reefs are demonstrated by the reef taxa distribution (Supplementary material S1), the corresponding cluster analysis and ANOSIM (Fig. 6).

Microfacies analyses and reef component relative abundances reveal additional differences between the lithologically and biotically distinct reef limestones (see section 5.4), leading us to 
reliably distinguish two distinct types of reef. The grey limestone clasts in the VCM breccia are characterized by microbialite-dominated, sponge-microproblematica reefs with more interstitial sediments and a very loose reef framework (Reef Type 1), whereas the massive white limestone slabs typically correspond to sponge-dominated reefs with ooid-peloid-bioclastic grainstone that infill the voids within an important reef framework (Reef Type 2). Corals are occasionally present in both types of reef but remains minor components of the framework.

The key characteristics of each type of reef are summarized in Table 5. It is worth noting that, according to its biotic content, the reef limestone from Loc. 10 Road 28 (Fig. 1) more closely corresponds to Reef Type 2. However, their mode of occurrence, as clast in VCM breccia, and the unclear pattern presented by the relative abundances of reef components places doubt on the attribution to the Reef Type 2. We hypothesize that the reef limestone from Loc. 10 Road 28 may represents a transitional stage between Reef Type 1 and Reef Type 2.

The clear differences between the two types of reefs can be explained by temporal, geographical and ecological factors:

- They correspond to different ages;

- They are related to different depositional settings of the carbonate platform. For example, they may represent depth-related environmental variations and/or reflect the reef zonation;

- They indicate coeval but different biotic associations of reef organisms.

These three explanations are not exclusive of each other and may both play a role in the processes that led to the differences between the two reef types. As a consequence, biostratigraphic data are pivotal to discriminate between time-related differences and ecological differences.

\subsection{Biostratigraphy}


This section discusses the published biostratigraphic data of the SAC, as well as the dating of the two types of reefs on the basis of reef assemblages and conodont biostratigraphy. Former studies of the SAC limestone described several Upper Triassic biostratigraphic markers (e.g., Conodonts: Yamato Omine Research Group, 1981; Ishida and Hirsh, 2001; Onoue and Tanaka,2005; Onoue and Sano, 2007; Foraminifers: Kristann Tollmann, 1991; Chablais et al., 2011; Sponges: Chablais et al., 2010b; Senowbari-Daryan et al., 2012; Peybernes et al., 2015; and Corals: Kanmera, 1964; Okuda et al., 2005; Stanley and Onoue, 2015). Accordingly, the Sambosan limestone has been attributed to the Ladinian? to Rhaetian interval. Concerning reef facies in particular, the earliest reported evidence is of the Carnian reef biota from the limestone clasts at the Koguchi locality at Kyushu Island (Senowbari-Daryan et al., 2012) and the Ladinian?-Carnian reef limestone clasts from Loc. 3 Tsuno, Loc. 5 Mt. Sambosan 2, Loc. 8 Mt. Ishidate 2 and Loc. 9 Konose Kyo at Shikoku Island (Peybernes et al., 2015). Younger Norian bioconstruction are represented by the Lower-Middle Norian reef at Kamase locality at Kyushu Island (Onoue and Stanley, 2008) and the Norian reef at Loc. 1 Inaba cave, Shikoku Island (Chablais et al., 2010b). Moreover, Carnian and Norian corals have been reported at Kyushu (Kanmera, 1964; Stanley and Onoue, 2015), Shikoku (Okuda et al., 2005; Stanley and Onoue, 2015) and the Kii Peninsula (Yamato Omine Research Group, 1976; Okuda and Yamagiwa, 1978; Okuda, 2006).

\section{Conodont biostratigraphy}

Conodonts have been the subject of several investigations in the SAC (Yamato Omine Research Group, 1981; Ishida and Hirch, 2001; Onoue and Tanaka, 2005; Onoue and Sano, 2007; Yoshida and Onoue, 2008). Most of the studies focused on chert or deep water limestone and rarely described the related microfacies. In this work, we specifically investigated shallow water limestone in particular and considered the microfacies of the samples from which the conodonts 
were retrieved. Surprisingly, among the different microfacies that were recognized (i.e., slope to lagoonal microfacies), conodonts were found only in reef limestone. Their occurrence in this facies in particular can be explained by the deposition of reef limestone at the platform margin, facing the open ocean where conodonts thrived.

The conodont element Parvigondolella? sp., found at Loc.1 Inaba, indicates a Late NorianRhaetian age for the massive limestone slabs of this locality. This is in agreement with the assemblage-based biostratigraphy proposed by Chablais et al. (2010) and this paper.

The reef limestone sample from Loc. 6 Befu contains the brachiopod Gosaukamerella eomesozoica, encrusting microproblematica and undetermined foraminifers. Unfortunately, strong recrystallization prevents microfacies correlations with other limestone units. Nevertheless, the conodont fauna indicates a Late Carnian age (see section 5.1) and thus constitute important biostratigraphic data for the dating of limestone units in this area.

At Loc. 4 Mt. Sambosan 1 Primatella stanleyi and Krassodontus roberti indicates a Late Carnian age for this massive limestone slab (Reef Type 2).The conodonts Epigondolella postera and Epigondolella abnetis, reported from the massive limestone slab unit at Loc. $4 \mathrm{Mt}$. Sambosan 1.by the Yamato Omine Research Group (1981) suggest to extend the age to the Norian. Therefore, the massive limestone slabs corresponding to Reef Type 2 are attributed to the Late Carnian-Norian-Rhaetian?. On the other hand, limestone samples corresponding to Reef type 1 do not contain conodonts. Therefore, age attribution of Reef Type 1 rely on assemblage-based biostratigraphy.

\section{Assemblage-based biostratigraphy}

Reef fauna assemblages often allow a biostratigraphic differentiation between Carnian and Norian-Rhaetian reefs (Bernecker, 2005). Indeed, Norian-Rhaetian reefs differ considerably from Carnian reefs with regard to their taxonomic composition and diversity (Flügel, 2002). In 
Oman, for example, Upper Triassic reefs have been dated by their associations of reef builders and dwellers (Bernecker, 2005). The Carnian fauna used for age determination consist of corals (Volzeia badiotica, Rhopalodendron juliensis, and Margarophyllia crenata), sponges (Cryptocoelia zitteli, Zardinia sp. and Uvanella irregularis), serpulids (Barbafera carnica), foraminifers (Paraophtalmidium sp. and Bispirinella ovata=Cucurbita infundibuliforme according to Gale et al., 2012) and the microproblematicum Ladinella porata (Bernecker 2005). Conversely, typical Norian-Rhaetian fauna are characterized by foraminifers (Cucurbita spp., Kaeveria fluegeli, Galeanella spp., Alpinophragmium perforatum) and the problematicum Microtubus communis (Bernecker 1996, 2005). M. communis in particular, is considered to be a marker of the central part of the Norian-Rhaetian reefs (Flügel, 2004).

In the SAC of Shikoku, Cryptocoelia zitteli, Zardinia sp., Uvanella irregularis and Ladinella porata are present among other Ladinian?-Carnian taxa in samples corresponding to Reef Type 1 at Loc. 3 Tsuno, Loc. 5 Mt. Sambosan 2, Loc. 8 Mt. Ishidate 2, and Loc. 9 Konose Kyo (Peybernes et al., 2015). Galeanella spp., Alpinophragmium perforatum and Microtubus communis occur at Loc. 1 Inaba (Chablais 2010), Loc. 2 Tsuno windmill, Loc. 4 Mt. Sambosan 1 and Loc. 7 Mt. Ishidate 1. These occurrences, characterizing the Reef Type 2, are thus indicative of a Norian age and are consistent with the conodont biostatigraphy. However, it is to be noticed that in Japan, the Cucurbita spp. are found predominantly in the limestone clasts assumed to be Ladinian?-Carnian while they have also been reported from the Norian-Rhaetian in Oman.

Additional Norian markers from the massive limestone slabs (Reef Type 2) are Decapoalina schaeferae (= "Sigmoilina" schaeferae) (Gale et al., 2013b) and Actinotubella gusici (Senowbari-Daryan, 1984) as well as an abundance of Chaetetid sponges. Indeed, according to Flügel (2002), Chaetetid sponges are increasingly frequent during the Norian-Rhaetian. 
The cluster analysis, including worldwide Upper Triassic reef fauna (see section 5.5), indicates that the taxonomic composition of Ladinian-Carnian reef fauna considerably differs from that of the Norian-Rhaetian (Fig. 10). In the resulting dendrogram, the biotic assemblage of Reef Type 1 clusters exclusively with Ladinian-Carnian reef fauna, whereas the biotic assemblage of Reef Type 2 belongs to a cluster exclusively composed of Norian-Rhaetian reef fauna. Therefore, our cluster analysis confirms the Ladinian?-Carnian age of Reef Type 1 and the Norian-Rhaetian age of Reef Type 2.

The taxa showing the highest contribution to this two-cluster structuring in the SIMPER analysis (i.e., Ladinella, Plexoramea, Zardinia, Jablonskya, and Alpinothalamia. for the Ladinian-Carnian and Alpinophragmium, Decapoalina, Galeanella, Paradeningeria and Microtubus for the Norian Rhaetian, see section 5.5) can be considered the best biostratigraphic markers (i.e., short range and wide distribution) of our dataset, in spite of their overall low percentages of contribution to the between-cluster taxonomic dissimilarity. Indeed, they correspond to taxa typically considered to be biostratigraphically relevant (see section 6.3). The SIMPER analysis, therefore, quantitatively confirms the typically qualitative biostratigraphic statements. Most of the relevant biostratigraphic markers (according to the SIMPER analysis) are present in Japan. It is also worth noting that foraminifers do not appear as the most significant biostratigraphic markers in the Ladinian-Carnian, although they include the three most important biostratigraphic markers (i.e., Alpinophragnmium, Decapoalina and Galeanella) in the Norian-Rhaetian.

The conodont biostratigraphy and the reef assemblages suggest that the differences between the two types of reef result from their different ages. Similarly, Okuda et al. (2005) have already proposed a Norian age for white limestone slabs at Loc. 4 Mt. Sambosan 1, whereas grey limestone clasts in breccia at Loc. 5 Mt. Sambosan 2 ("gray limestone included within the greenstone" in Okuda et al. 2005) are supposed to be Carnian in age, based on coral occurrences 
(Craspedosmilia graeca, Margarophyllia capitata, Pamiroseris sp., Cassianastrea ruessi) and facies affinity. Nevertheless, these authors only developed their view for the Mt. Sambosan localities. Here we suggest this statement be extended to most of the outcrops of the central and eastern Shikoku Island. Furthermore, a similar pattern in the mode of occurrence is observed at Kyushu Island. The coral and foraminifer assemblages and facies affinity of the larger limestone units at the Kamase locality indicate an Early to Middle Norian age (Onoue and Stanley, 2008), whereas limestone clasts in VCM breccia at the Koguchi locality clearly contain Carnian reef fauna (Kanmera, 1964; Senowbari-Daryan et al., 2012).

In summary, according to the different lines of evidence discussed above, we are able to clearly distinguish two types of reefs corresponding to different ages: Ladinian?-Lower Carnian Reef Type 1 (occurring as clasts in VCM breccia) and Upper Carnian-Norian to Rhaetian? Reef Type 2 (mainly present in massive limestone slabs). As demonstrated above, the lithologic, petrographic, and biostratigraphic distinction between the two types of reefs is reliable, despite some local uncertainties (e.g., reef limestone from Loc. 10 Road 28 has more affinity with Reef Type 2 but occurs as clasts in VCM breccia). Additionally, it should be noted that neither massive limestone slabs nor limestone clasts in VCM breccia are exclusively of reefal facies. Nevertheless, our results from reef limestone provide a robust framework for further investigations.

\subsection{Reef evolution}

Reef limestone from the SAC of Shikoku records the evolution of a reef environment from the Ladinian?-Early Carnian to the Late Carnian-Norian-Rhaetian? and, provides pivotal information regarding reef evolution in the Panthalassa Ocean. The ages of the two types of 
reefs present in the SAC roughly correspond to the two main reef blooms that occurred during the Triassic (Earliest Carnian and Late Norian), as described by Flügel (2002).

The Late Carnian-Early Norian corresponds to an important reef fauna turnover and represents the transition between typical Ladinian-Carnian to Norian-Rhaetian reef fauna (Flügel, 2002). Transitional reef assemblages have been described from the Late Carnian to Early Norian in the Northern Calcareous Alps (Martindale et al. 2013b). According to our results, Upper Carnian reef fauna of the SAC appear to have more affinity with Norian-Rhaetian assemblages than to the Lower Carnian ones.

In Reef Type 1, point counting analyses reveal that the volume occupied by the reef framework is relatively low, whereas peloidal and clotted micrite is abundant. Similar build-ups with reduced framework and high microbialite content are known from American terranes, especially those of higher paleolatitudes (Lime Peak, Yukon: Reid and Ginsburg, 1986; British Columbia: Martindale et al. 2010; Summit Point, Oregon: Martindale et al., 2012, 2015) and Ladinian-Carnian reefs of the western Tethys (Russo et al., 1997).

In Reef Type 2, calcareous sponges increased dramatically in importance. Data of relative abundances clearly indicates the dominance of calcareous sponges, especially in Loc. 1 Inaba cave and Loc.7 Mt. Ishidate.

In summary, we observe an evolution from microbialite-rich, Ladinian?-Lower Carnian sponge-microproblematica reefs to sponge-dominated, Upper Carnian-Norian-Rhaetian? reefs. This trend corresponds roughly to the reef evolution observed in the Tethys (e.g., Flügel, 2002; Tosti et al., 2014). The Middle and early Late Triassic is characterized by Permian-like reef construction dominated by Tubiphytes, calcareous sponges and microbialites (Stanley, 1988; Payne et al., 2006; Tosti et al., 2014). Conversely, Norian-Rhaetian build-ups are dominated by calcareous sponges and corals with superstratal growth fabrics (Flügel, 2002). 
Another striking observation is the low abundance of coral colonies in the Upper Triassic of Japan and especially the lack of high growing coral reefs. This reef community usually characterizes the Rhaetian reefs in the Tethys (Schäfer, 1979; Benercker et al., 1999). This could be explained either by the absence of Rhaetian reefs in the SAC or by different reef fauna assemblages in the Panthalassa during the Rhaetian. Coral reefs of the East Panthalassa are typically characterized by many coral ecomorphotypes (platy, massive, and branching), whereas those of the northern Tethys are dominated by phaceloid branching colonies (Martindale et al., 2015). In Japan, massive and platy corals are rare and phaceloid branching ecomorphotype dominates, as in the Tethys.

\subsection{Reef paleobiogeography}

Quantitative analyses (see section 5.5) provide valuable insights regarding reef biodiversity and reef biogeographical affinities during the Late Triassic. According to our dataset, South Tethys and Panthalassa reefs exhibit lower generic richness than West and North Tethys reefs (Fig. 9). Other authors have stated that most Panthalassan reefs are of moderate to low diversity (e.g., Flügel, 2002). The lower generic richness may partly be explained by the fewer number of studies in these regions compared to classical North Tethys reef localities. However, because the South Tethys and Panthalassa localities considered in this work are known and have been studied for decades, it seems reasonable to consider that the lower generic richness is, at least partly, a genuine biodiversity pattern. The high diversity of the North and West Tethys margin reefs suggests that these areas may represent a center of diversity during the Late Triassic, similar to the one observed in the modern Western Pacific for scleractinian corals and larger foraminifers (Belasky, 1996). Our data also show an eastward decrease in generic richness similar to the eastward decline in diversity of the Indo-Pacific coral fauna (Grigg and Hey, 1992; Belasky and Runnegar, 1993). Concerning the northeastern Panthalassa, the lower 
generic richness could be also explained by eastern boundary currents (Martindale et al., 2015). These authors argued that eastern boundary currents possibly "bathed North American reefs in cool waters and drove the upwelling of cold, nutrient-rich waters onto the shelf and around islands".

Generic endemism, estimated by the number of uniques, is generally low, except for the Dolomites in the Ladinian-Carnian and Sicily, Iran and Turkey in the Norian-Rhaetian. These areas are also often characterized by the high generic richness of their sponge fauna. Nevertheless, the relatively low endemism of the other reef areas suggests that no major barrier (geographical or ecological) for fauna dispersion was present in the intertropical zone during the Late Triassic. In particular, reef biota from the SAC is comprised of very few uniques, suggesting a relatively low endemism of reef fauna in Western Panthalassa during the Late Triassic. This result contrasts with previous statements regarding the high endemism of coral fauna of the SAC (Stanley and Onoue, 2015). The overall higher proportion of uniques among sponge genera compared to foraminifers and microproblematica could indicate that these organisms are less prone to efficient dispersion (which primarily occurs during the larval stage) and/or are less ecologically tolerant.

All of the reef areas studied here are considered to have been in the intertropical belt during the Late Triassic. Therefore, no significant latitudinal patterns are expected. However, a longitudinal biogeographic gradient in fauna distribution seems likely. Longitudinal faunal exchanges and connections between the Tethys and the Panthalassa during the Late Triassic were discussed by Kristan-Tollmann and Tollmann (1981), Newton (1988, 1990), Smith and Westermann (1990), Stanley and Yancey (1990), Stanley (1994), Chablais et al. (2011), and Martini and Rigaud (2014). The tropical eastern Pacific Ocean has been described as the most effective barrier (East Pacific Barrier) to the dispersal of warm water shelf fauna in modern oceans (Eckman, 1953; Grigg and Hey, 1992; Belasky, 1996). The Panthalassa ocean, which 
was approximately twice as wide as the equatorial Pacific today (Flügel, 2002), should have represented to some extent a biogeographic barrier for reef biota dispersion, leading to a more pronounced provincialism than today (Belasky et al., 2002). Nevertheless, seamount swarms and terranes may have acted as stepping stones for reef biota migration allowing intertropical trans-Panthalassic connections (Tozer 1982, Stanley, 1994).

Several authors stated and emphasized the Tethyan affinity of the SAC biota (Kanmera, 1964; Tamura, 1990, 1992; Kristan-Tollmann, 1991; Chablais et al., 2011; Senowbari-Daryan et al., 2012; Peybernes et al., 2015). However, their statements were based on qualitative observations and comparisons between uneven geographic areas (i.e., comparison of local outcrop with wide regions). Our results allow us to quantitatively assess for the first time the biogeographical affinity of the SAC reef fauna with the Tethyan ones.

The cluster analysis, based on a taxonomically homogenous dataset, provides insights into the biostratigraphy and biogeography of the Late Triassic reef fauna. However, the resulting UPGMA dendrogram (Fig. 10) shows a rather low cophenetic correlation index of 0.79 , indicating that it does not perfectly described the observed among-assemblage similarities. As the ordination analyses (PCoA and NMDS) of the same Dice similarity matrix do not evidence any clear gradational structure in the analyzed dataset (results not shown here), this is likely to be due to some inescapable sampling noises ultimately affecting the ultrametric (i.e., hierarchical) similarity structuring. As discussed above, the dendrogram independently confirms the attribution of the Japan Reef Type 1 and Japan Reef Type 2 to different time intervals (Ladinian?-Carnian and Late Carnian-Norian to Rhaetian?, respectively) but cluster analysis also allows us to tentatively explore the faunal relationship and global biogeographic patterns.

For the Ladinian-Carnian interval the Japanese reef assemblage is clearly more related to their South Tethys counterpart (Oman) than to their North and West Tethys counterparts (Figs. 10, 
11). This confirms previous statements regarding the biogeographic affinity of Upper Triassic fauna of the SAC (Chablais et al., 2011; Senowbari-Daryan et al., 2012). However, the scarcity of Ladinian-Carnian reef fauna in North American terranes and craton prevents quantitative comparison with coeval Tethyan and West Panthalassa reefs. Therefore, biogeographic connections between West and East Panthalassa are probably missed due to this lack of data. Greece and Turkey assemblages show similarities that are consistent with their paleogeographic locations. North Tethys reef fauna are closely related to each other and the reef assemblage from Sicily appears to be isolated.

For the Norian-Rhaetian interval, Japanese reef fauna shows a strong affinity with the reef fauna from Oman, as in the Ladinian-Carnian interval. Moreover, the fauna affinity between the Yukon (i.e., Stikinia terrane) and Japan and Oman suggests that longitudinal migrations of reef fauna were effective in the Panthalassa Ocean during the Norian. However, the lack of diversified reef fauna on the American craton prevents a complete understanding of eastern Panthalassa reef biogeography during the Late Triassic. The weak similarity between the Yukon and Oregon reef fauna $\left(S_{\text {Dice }}=0.39\right)$ is a puzzling result that questions the connections between the corresponding Stikinia and Wallowa terranes. In the Norian-Rhaetian interval, the fauna of Sicily, Northern Calcareous Alps and Iran show strong affinities to each other. In summary, according to our results, SAC reef faunas are more related to the South Tethys reef assemblages in the Ladinian-Carnian and Norian-Rhaetian. Moreover, in the Norian-Rhaetian, South Tethys (Oman) and West Panthalassa (Japan), the reef fauna show affinities with East Panthalassa reef fauna of the Stikinia terrane (Yukon).

Biogeographic data often help to constrain paleogeographic reconstructions (e.g., Belasky and Runnegar, 1994; Aberhan, 1998; Johnston and Borel, 2007; Brayard et al., 2009; Chablais et al. 2011). Nevertheless, the similarities between fauna should not be translated directly into the geographic distances that separate them (Belasky, 1996). These paleobiogeographical patterns 
need to be confirmed with other taxa from various environments. In-depth investigations of poorly studied localities are also needed to better assess biogeographic latitudinal and longitudinal gradients. Our quantitative approach of integrated reef fauna biogeography appears to be fruitful and requires further investigations involving other taxonomic groups, additional localities and complementary quantitative methods such as network-based analyses (e.g., computing Bootstrapped Spanning Networks; Brayard et al., 2007, 2009, 2015) or probabilistic approaches. Moreover, the development of global databases such as the Paleobiology Database, providing increasingly more data, is promising for the improvement of paleobiogeographical models.

\section{Conclusion}

Ten localities (including two new localities) with Upper Triassic reef limestone from the Sambosan Accretionary Complex at Shikoku Island were extensively sampled. Field observations, biotic composition analysis, quantitative assessment of reef components and integrated biostratigraphy (conodont and reef assemblages) lead us to distinguish two types of reefs that differ in their mode of occurrence, reef fauna assemblages and reef component relative abundances. We propose a Ladinian?-Lower Carnian age for the grey reef limestone occurring as clasts embedded in a volcaniclastic matrix (Reef Type 1) and a Upper CarnianNorian to Rhaetian? age for the reef limestone that crops out as massive white limestone slabs (Reef Type 2). These findings highlight the reef evolution on Panthalassa seamounts, from microbialite-rich, sponge-microproblematica reefs during the Ladinian?-Early Carnian to sponge-dominated reefs during the Late Carnian-Norian to Rhaetian?. This evolution is closely comparable to reef evolution in the Tethys Ocean. Hierarchical cluster analyses and associated multivariate statistical treatments strengthen the South Tethys affinity of the reef biota from the 
SAC during the Ladinian?-Early Carnian and the potential connections with American terranes in the Norian-Rhaetian.

The results presented in this paper contribute to the better understanding of reef evolution and biogeography during the Late Triassic. This study provides useful information for further paleobiodiversity analyses and paleogeographic reconstruction and leads to a more accurate comprehension of paleobiogeographic patterns during the Middle and Late Triassic.

\section{Acknowledgments}

This contribution is part of the REEFCADE projects (Swiss National Science Foundation \#200020-156422 and 200020-137661). We thank Daisuke Yamashita for his help in the field and Mike Orchard for the conodont determination.

\section{References}

Aberhan, M., 1998. Paleobiogeographic patterns of pectinoid bivalves and the Early Jurassic tectonic evolution of western Canadian terranes. Palaios 13, 129-148.

Aberhan, M., 2001. Bivalve palaeobiogeography and the Hispanic Corridor: time of opening and effectiveness of a proto-Atlantic seaway. Palaeogeogr. Palaeoclimatol. Palaeoecol. 165, 375394.

Arias, C., 2006. Northern and Southern Hemispheres ostracod palaeobiogeography during the Early Jurassic: Possible migration routes. Palaeogeogr. Palaeoclimatol. Palaeoecol. 233, 63-95.

Baselga, A., 2010. Partitioning the turnover and nestedness components of beta diversity. Glob. Ecol. Biogeogr. 19, 134-143.

Baselga, A., 2012. The relationship between species replacement, dissimilarity derived from nestedness, and nestedness. Glob. Ecol. Biogeogr. 21, 1223-1232.

Belasky, P., 1996. Biogeography of Indo-Pacific larger foraminifera and scleractinian corals: a probabilistic approach to estimating taxonomic diversity, faunal similarity, and sampling bias. Palaeogeogr. Palaeoclimatol. Palaeoecol. 122, 119-141.

Belasky, P., Runnegar, B., 1993. Biogeographic constraints for tectonic reconstructions of the Pacific region. Geology 21, 979-982.

Belasky, P., Runnegar, B., 1994. Permian longitudes of Wrangellia, Stikinia, and Eastern Klamath terranes based on coral biogeography. Geology 22, 1095-1098.

Belasky, P., Stevens, C.H., Hanger, R.A., 2002. Early Permian location of western North American terranes based on brachiopod, fusulinid, and coral biogeography. Palaeogeogr. Palaeoclimatol. Palaeoecol. 179, 245-266. 
Bernecker, M., 1996. Upper Triassic reefs of the Oman mountains: Data from the South Tethyan margin. Facies 34, 41-76.

Bernecker, M., 2005. Late Triassic reefs from the Northwest and South Tethys: distribution, setting, and biotic composition. Facies 51, 442-453.

Bernecker, M., Weidlich, O., Flugel, E., 1999. Response of Triassic reef coral communities to sealevel fluctuations, storms and sedimentation: Evidence from a spectacular outcrop (Adnet, Austria). Facies 40, 229-279.

Blendinger, W., 1994. The carbonate factory of Middle Triassic buildups in the Dolomites, Italy: a quantitative analysis. Sedimentology 41, 1147-1159. doi:10.1111/j.1365-3091.1994.tb01446.x

Bole, B., 2002. Karbonatne kamnine Pece. Geologija 45, 59-69.

Boni, M., Iannace, A., Torre, M., Zamparelli, V., 1994. The Ladinian-Carnian reef facies of Monte Caramolo (Calabria, Southern Italy). Facies 30, 101-117.

Brandner, R., Flügel, E., Senowbari-Daryan, B., 1991. Microfacies of carbonate slope boulders: indicator of the source area (Middle Triassic: Mahlknecht Cliff, Western Dolomites). Facies 25, 279-295.

Brayard, A., Escarguel, G., 2013. Untangling phylogenetic, geometric and ornamental imprints on Early Triassic ammonoid biogeography: a similarity- distance decay study. Lethaia 46, 19-33.

Brayard, A., Escarguel, G., Bucher, H., 2007. The biogeography of Early Triassic ammonoid faunas: clusters, gradients, and networks. Geobios 40, 749-765.

Brayard, A., Escarguel, G., Bucher, H., Brühwiler, T., 2009. Smithian and Spathian (Early Triassic) ammonoid assemblages from terranes: Paleoceanographic and paleogeographic implications. J. asian earth Sci. 36, 420-433.

Brayard, A., Escarguel, G., Monnet, C., Jenks, J.F., Bucher, H., 2015. Biogeography of Triassic ammonoids, in: Ammonoid Paleobiology: From Macroevolution to Paleogeography. Springer, pp. $163-187$.

Brayard, A., Vennin, E., Olivier, N., Bylund, K.G., Jenks, J., Stephen, D.A., Bucher, H., Hofmann, R., Goudemand, N., Escarguel, G., 2011. Transient metazoan reefs in the aftermath of the endPermian mass extinction. Nat. Geosci. 4, 693-697.

Burne, R. V, Moore, L.S., 1987. Microbialites: organosedimentary deposits of benthic microbial communities. Palaios 241-254.

Buser, S., Ramovš, A., Turnšek, D., 1982. Triassic reefs in Slovenia. Facies 6, 15-23.

Carrillat, A., Martini, R., 2009. Palaeoenvironmental reconstruction of the Mufara Formation (Upper Triassic, Sicily): High resolution sedimentology, biostratigraphy and sea-level changes.

Palaeogeogr. Palaeoclimatol. Palaeoecol. 283, 60-76.

Chablais, J., 2010. Sedimentology and biostratigraphy of the Upper Triassic atoll-type carbonates of the Sambosan Accretionary Complex (panthalassan domain; Japan). University of Geneva.

Chablais, J., Martini, R., Kobayashi, F., Stampfli, G.M., Onoue, T., 2011. Upper Triassic foraminifers from Panthalassan carbonate buildups of Southwestern Japan and their paleobiogeographic implications. Micropaleontology 57, 93-124.

Chablais, J., Martini, R., Samankassou, E., Onoue, T., Sano, H., 2010a. Microfacies and depositional setting of the Upper Triassic mid-oceanic atoll-type carbonates of the Sambosan Accretionary Complex (southern Kyushu, Japan). Facies 56, 249-278.

Chablais, J., Onoue, T., Martini, R., 2010b. Upper Triassic reef-limestone blocks of southwestern Japan: New data from a Panthalassan seamount. Palaeogeogr. Palaeoclimatol. Palaeoecol. 293, 206-222. 
Chafetz, H.S., 1986. Marine peloids: a product of bacterially induced precipitation of calcite. J. Sediment. Res. 56, 812-817.

Cheetham, A.H., Hazel, J.E., 1969. Binary (presence-absence) similarity coefficients. J. Paleontol. $1130-1136$.

Clarke, K.R., 1993. Non-parametric multivariate analyses of changes in community structure. Aust. J. Ecol. 18, 117.

Di Bari, D., Laghi, G.F., 1994. Involutinidae Bütschli (Foraminiferida) in the Carnian of the northeastern Dolomites (Italy). Mem. di Sci. Geol. 46, 93-118.

Di Stefano, P., Gullo, M., Senowbari-Daryan, B., 1990. The Upper Triassic reef of Monte Genuardo (southwestern Sicily). Boll. della Soc. Geol. Ital. 109, 103-114.

Dieci, G., Antonacci, A., Zardini, R., 1968. Le spugne cassiane (Trias medio-superiore) della regione dolomitica attorno a Cortina d'Ampezzo. Bolletino della Soc. Paleontol. Ital. 7, 94-155.

Dragastan, O., Kube, B., Richter, D., 1999. New late Triassic calcareous algae from Hydra, Greece. Acta Palaeontol. Rom. 2, 139-156.

Dullo, W.-C., Flügel, E., Lein, R., Riedel, P., Senowbari-Daryan, B., 1987. Algen, Kalkschwämme und Mikroproblematika aus unterkarnischen Riffkalken des Bosruck-Gipfels (Nördliche Kalkalpen, Österreich). Jb. Geol. B.-A 129, 4.

Dullo, W.-C., Lein, R., 1982. Facies and environment of the Leckkogel beds (Carnian; Alps). Facies 6, $25-35$.

Ekman, S., 1953. Zoogeography of the sea, 417 pp. London: Sidgwick \& Jackson 953.

Emmerich, A., Zamparelli, V., Bechstädt, T., Zühlke, R., 2005. The reefal margin and slope of a Middle Triassic carbonate platform: the Latemar (Dolomites, Italy). Facies 50, 573-614.

Everts, A.J.W., Reijmer, J.J.G., 1995. Clinoform composition and margin geometries of a Lower Cretaceous carbonate platform (Vercors, SE France). Palaeogeogr. Palaeoclimatol. Palaeoecol. $119,19-33$

Fagerstrom, J.A., Weidlich, O., 2005. Biologic response to environmental stress in tropical reefs: lessons from modern Polynesian coralgal atolls and Middle Permian sponge and Shamovellamicrobe reefs (Capitan Limestone USA). Facies 51, 501-515.

Flügel, E., 1981. Paleoecology and facies of Upper Triassic reefs in the Northern Calcareous Alps, in: Toomey, D.F. (Ed.), European Fossil Reef Models. Special Publications of SEPM, pp. 291-359.

Flügel, E., 1986. Zur Mikrofazies oberanisischer Riffkalke in den östlichen Nordkarawanken, Kärnten. Carinthia II 176, 463-478.

Flügel, E., 2002. Triassic reef patterns, in: Kiessling Wolfgang, Flügel, E., Golonka, J. (Eds.), Phanerozoic Reef Patterns. Special Publications of SEPM, pp. 391-463.

Flügel, E., 2004. Microfacies of Carbonate Rocks Analysis, Interpretation and Application, Interpretation A Journal Of Bible And Theology. Springer.

Flügel, E., Velledits, F., Senowbari-Daryan, B., Riedel, P., 1992. Rifforganismen aus "Wettersteinkalken"(Karn?) des Bükk-Gebirges, Ungarn. Geol. Paläont. Mitt. Innsbruck 18, 35 62 .

Gale, L., 2012. Rhaetian foraminiferal assemblage from the Dachstein Limestone of Mt. Begunjscica (Kosuta Unit, eastern Southern Alps). Geologija 55, 17-44.

Gale, L., Kastelic, A., Rozic, B., 2013a. Taphonomic features of Late Triassic Foraminifera from Mount Begunjscica, Karavanke Mountains, Slovenia. Palaios 28, 771-792.

Gale, L., Rettori, R., Martini, R., 2012. Critical review of Pseudocucurbitidae (Miliolina, 
Foraminiferea) from the Late Triassic reef environments of the Tethyan area. J. Micropalaeontology 31, 179-186.

Gale, L., Rettori, R., Martini, R., Rožič, B., 2013b. Decapoalina n. gen.(Miliolata, Milioliporidae; Late Triassic), a new foraminiferal genus for "Sigmoilina" schaeferae Zaninetti, Altiner, Dager \& Ducret, 1982. Boll. della Soc. Paleontol. Ital. 52, 82.

García-Bellido, D.C., Rodríguez, S., 2005. Palaeobiogeographical relationships of poriferan and coral assemblages during the late Carboniferous and the closure of the western Palaeotethys SeaPanthalassan Ocean connection. Palaeogeogr. Palaeoclimatol. Palaeoecol. 219, 321-331.

Gaździcki, A., Reid, P., 1983. Upper Triassic Involutinidae (Foraminifera) of Lime Peak in Yukon, Canada. Acta Geol. Pol. 33, 99-106.

Gischler, E., Lomando, A.J., 1999. Recent sedimentary facies of isolated carbonate platforms, BelizeYucatan system, Central America. J. Sediment. Res. 69.

Grigg, R.W., Hey, R., 1992. Paleoceanography of the tropical eastern Pacific Ocean. Science (80-. ). $255,172$.

Gusic, I., Wohlfeil, H., Wohlfeil, K., 1984. Zur Altersstellung und Fazies des Kalkes von Kalecik (Devon) und der Akdag-Serie (Trias) im nordöstlichen Teil von Karaburun (west. Izmir, Türkei). N Jb Geol Paläont Abh 167, 375-404.

Hopkin, E., 2009. Late Carnian (Late Triassic) conodont and ammonoid paleontology of Wrangellia. University of British Columbia.

Ishida, K., Hirsch, F., 2001. Taxonomy and faunal affinity of late Carnian-Rhaetian conodonts in the Southern Chichibu Belt, Shikoku, SW Japan. Riv. Ital. di Paleontol. e Stratigr. 107, 227-250.

Ishizuka, H., Miyake, M., Takeda, N., 2003. Origin and metamorphism of greenstones from the Sanbosan unit of the Southern Chichibu Belt, west to central east Shikoku. J. Geol. Soc. Japan $109,267-279$.

Johnston, S.T., Borel, G.D., 2007. The odyssey of the Cache Creek terrane, Canadian Cordillera: Implications for accretionary orogens, tectonic setting of Panthalassa, the Pacific superwell, and break-up of Pangea. Earth Planet. Sci. Lett. 253, 415-428.

Kanmera, K., 1964. Triassic coral faunas from the Konosé Group in Kyushu. Mem Fac Sci Kyushu Univ Ser D 15, 117-147.

Kanmera, K., 1969. Litho-and bio-facies of Permo-Triassic geosynclinal limestone of the Sambosan Belt in southern Kyushu. Spec Publ Palaeontol Soc Jpn 14, 13-39.

Keim, L., Schlager, W., 1999. Automicrite facies on steep slopes (Triassic, Dolomites, Italy). Facies $41,15-25$.

Kiessling, W., 2010. Reef expansion during the Triassic: spread of photosymbiosis balancing climatic cooling. Palaeogeogr. Palaeoclimatol. Palaeoecol. 290, 11-19.

Kiessling, W., Flügel, E., 2000. Late Paleozoic and Late Triassic limestones from North Palawan block (Philippines): microfacies and paleogeographical implications. Facies 43, 39-77.

Kiessling, W., Flügel, E., 2002. Paleoreefs - a database on Phanerozoic reefs, in: Kiessling, W., Golonka, J., Flugel, E. (Eds.), Phanerozoic Reef Patterns. Special Publications of SEPM.

Kiessling, W., Flügel, E., Golonka, J., 1999. Paleoreef maps: evaluation of a comprehensive database on Phanerozoic reefs. Am. Assoc. Pet. Geol. Bull. 83, 1552-1587.

Kobayashi, T., 1931. Notes on a new occurrence of Ladino-Carnic limestone at Sambosan, Tosa Province, Japan. Jpn J Geol Geogr 8, 251-258.

Kristan-Tollmann, E., 1991. Triassic Tethyan microfauna in Dachstein limestone blocks in Japan, in: 
International Symposium on Shallow Tethys 3. pp. 35-49.

Kristan-Tollmann, E., Tollmann, A., 1981. Die Stellung der Tethys in der Trias und die Herkunft ihrer Fauna. Mitt Österr Geol Ges 74, 129-135.

Krystyn, L., 1973. Zur Ammoniteli-und Conodonten-Stratigraphie der Hallstätter Obertrias (Salzkammergut, Österreich). Verh. Geol. B. A., Jg 113-153.

Marenco, P.J., Griffin, J.M., Fraiser, M.L., Clapham, M.E., 2012. Paleoecology and geochemistry of Early Triassic (Spathian) microbial mounds and implications for anoxia following the endPermian mass extinction. Geology 40, 715-718.

Martindale, R.C., Corsetti, F.A., Bottjer, D.J., Senowbari-Daryan, B., 2012. Microbialite fabrics and diminutive skeletal bioconstructors in Lower Norian Summit Point reefs, Oregon, United States. Palaios 27, 489-508.

Martindale, R.C., Corsetti, F.A., James, N.P., Bottjer, D.J., 2015. Paleogeographic trends in Late Triassic reef ecology from northeastern Panthalassa. Earth-Science Rev. 142, 18-37.

Martindale, R.C., Krystyn, L., Bottjer, D.J., Corsetti, F.A., Senowbari-Daryan, B., Martini, R., 2013a. Depth transect of an Upper Triassic (Rhaetian) reef from Gosau, Austria: Microfacies and community ecology. Palaeogeogr. Palaeoclimatol. Palaeoecol. 376, 1-21.

Martindale, R.C., Krystyn, L., Corsetti, F.A., Bottjer, D.J., 2013b. From fore reef to lagoon: evolution of the Upper Triassic Dachstein carbonate platform on the Tennengebirge (Salzburg, Austria). Palaios 28, 755-770.

Martindale, R.C., Zonneveld, J.-P., Bottjer, D.J., 2010. Microbial framework in Upper Triassic (Carnian) patch reefs from Williston Lake, British Columbia, Canada. Palaeogeogr. Palaeoclimatol. Palaeoecol. 297, 609-620.

Martini, R., Rigaud, S., 2014. The paleobiogeographic and stratigraphic distribution of Early Mesozoic foraminifers: toward a better understanding of large scale dispersal and recovery processes? nternational Symp. Foraminifera FORAMS 2014.

Matsuoka, A., 1992. Jurassic-Early Cretaceous Tectonic Evolution of the Southern Chichibu Terrane, Southwest Japan. Palaeogeogr. Palaeoclimatol. Palaeoecol. 96, 71-88.

Maurer, F., Reijmer, J.J.G., Schlager, W., 2003. Quantification of input and compositional variations of calciturbidites in a Middle Triassic basinal succession (Seceda, Dolomites, Southern Alps). Int. J. Earth Sci. 92, 593-609.

Newton, C.R., 1988. Significance of" Tethyan" fossils in the American Cordillera. Science (80-. ). 242, 385-391.

Newton, C.R., 1990. paleobiogeography of the ancient pacific-response. Science (80-. ). 249, 681683.

Niu, Y., Jiang, B., Huang, H., 2011. Triassic marine biogeography constrains the palaeogeographic reconstruction of Tibet and adjacent areas. Palaeogeogr. Palaeoclimatol. Palaeoecol. 306, 160175 .

Ogawa, Y., Taniguchi, H., 1989. Origin and emplacement of basaltic rocks in the accretionary complexes in SW Japan. Ofioliti 14, 177-193.

Okay, A.I., Altiner, D., 2004. Uppermost Triassic limestone in the Karakaya Complex-stratigraphic and tectonic significance. Turkish J. Earth Sci. 13, 187-199.

Okuda, H., 2006. The mode of limestones and the age of scleractinian corals from limestone blocks : Reexamination of corals from the Wasabidani complex in the central area of the Kii Mountains, Southwest Japan. Earth Sci. 60, 389-401.

Okuda, H., Ezaki, Y., Yao, A., 2005. Geological complexes of Sanbosan area and limestones 
containing Triassic scleractinian corals in Kochi Prefecture, southwestern Japan. Earth Sci. 59, 371-382.

Okuda, H., Yamagiwa, N., 1978. Triassic corals from Mt. Daifugen, Nara Prefecture southwest Japan. Trans Proc Palaeont Soc Japan NS 110, 297-305.

Olivier, N., Carpentier, C., Martin-Garin, B., Lathuilière, B., Gaillard, C., Ferry, S., Hantzpergue, P., Geister, J., 2004. Coral-microbialite reefs in pure carbonate versus mixed carbonate-siliciclastic depositional environments: the example of the Pagny-sur-Meuse section (Upper Jurassic, northeastern France). Facies 50, 229-255.

Onoue, T., Chablais, J., Martini, R., 2009. Upper Triassic reefal limestone from the Sambosan accretionary complex in Japan and its geological implication. J. Geol. Soc. Japan 115, 292-295.

Onoue, T., Nagai, K., Kamishima, A., Seno, M., Sano, H., 2004. Origin of basalts from Sambosan accretionary complex, Shikoku and Kyushu. J. Geol. Soc. Japan 110, 222-236.

Onoue, T., Sano, H., 2007. Triassic mid-oceanic sedimentation in Panthalassa Ocean: Sambosan accretionary complex, Japan. Isl. Arc 16, 173-190.

Onoue, T., Stanley, G.D., 2008. Sedimentary facies from Upper Triassic reefal limestone of the Sambosan accretionary complex in Japan: mid-ocean patch reef development in the Panthalassa Ocean. Facies 54, 529-547.

Onoue, T., Tanaka, H., 2005. Late Triassic bivalves from Sambosan accretionary complex, southwest Japan, and their biogeographic implications. Paleontol. Res. 9, 15-25.

Orchard, M.J., 2014. Conodonts from the Carnian-Norian Boundary (Upper Triassic) of Black Bear Ridge, Northeastern British Columbia, Canada. New Mexico Museum of Natural History and Science Bulletin 64, Albuquerque.

Payne, J.L., Lehrmann, D.J., Christensen, S., Wei, J., Knoll, A.H., 2006. Environmental and biological controls on the initiation and growth of a Middle Triassic (Anisian) reef complex on the Great Bank of Guizhou, Guizhou Province, China. Palaios 21, 325-343.

Peybernes, C., Chablais, J., Martini, R., 2015. Upper Triassic (Ladinian?-Carnian) reef biota from the Sambosan Accretionary Complex, Shikoku, Japan. Facies 61, 1-27.

Pfeiffer, J., 1988. Paleontology and microfacies of a platform margin in the Carnic Alps (Austria, Middle Triassic). Facies 19, 33-59.

Reid, R.P., 1987. Nonskeletal peloidal precipitates in upper Triassic reefs, Yukon Territory (Canada). J. Sediment. Res. 57, 893-900.

Reid, R.P., Ginsburg, R.N., 1986. The role of framework in Upper Triassic patch reefs in the Yukon (Canada). Palaios 590-600.

Reid, R.P., Macintyre, I.G., James, N.P., 1990. Internal precipitation of microcrystalline carbonate: a fundamental problem for sedimentologists. Sediment. Geol. 68, 163-170.

Reid, R.P., Tempelman-Kluit, D.J., 1987. Upper Triassic Tethyan-type reefs in the Yukon. Bull. Can. Pet. Geol. 35, 316-332.

Riding, R., 2000. Microbial carbonates: the geological record of calcified bacterial-algal mats and biofilms. Sedimentology 47, 179-214.

Riding, R., 2002. Structure and composition of organic reefs and carbonate mud mounds: concepts and categories. Earth-Science Rev. 58, 163-231. doi:10.1016/S0012-8252(01)00089-7

Riedel, P., 1990. Riffbiotope im Karn und Nor (Obertrias) der Tethys: Entwicklung, Einschnitte und Diversitätsmuster. University of Erlangen.

Roniewicz, E., 1989. Triassic scleractinian corals of the Zlambach Beds, Northern Calcareous Alps, 
Austria. Springer-Verlag.

Rosenblatt, M., 2010. Upper Triassic corals and Carbonate reef facies from the Martin Bridge and Hurwal Formations, Wallowa terrane (Oregon). University of Montana.

Rüffer, T., Zamparelli, V., 1997. Facies and biota of Anisian to Carnian carbonate platforms in the Northern Calcareous Alps (Tyrol and Bavaria). Facies 37, 115-136.

Russo, F., Neri, C., Mastandrea, A., Baracca, A., 1997. The mud mound nature of the Cassian Platform Margins of the Dolomites A case history: the Cipit boulders from Punta Grohmann (Sasso Piatto Massif, northern Italy). Facies 36, 25-36.

Safonova, I., Maruyama, S., Kojima, S., Komiya, T., Krivonogov, S., Koshida, K., 2015. Recognizing OIB and MORB in accretionary complexes: A new approach based on ocean plate stratigraphy, petrology and geochemistry. Gondwana Res.

Sánchez-Beristain, J.F., 2010. Paleoecological and geochemical studies on sponge-microencrusterbearing communities contained in selected Cipit Boulders from the St. Cassian Formation (Lower Carnian, Upper Triassic) of the Dolomites, northeastern Italy. Göttingen, Georg-August Universität, Diss., 2010.

Schäfer, P., 1979. Fazielle Entwicklung und palökologische Zonierung zweier obertriadischer Riffstrukturen in den Nördlichen Kalkalpen (“Oberrhät”-riff-kalke, Salzburg). Facies 1, 3-245.

Schäfer, P., Senowbari-Daryan, B., 1982. The Upper Triassic Pantokrator Limestone of Hydra (Greece): an example of a prograding reef complex. Facies 6, 147-163.

Scotese, C.R., 2014. Atlas of Middle \& Late Permian and Triassic Paleogeographic Maps, maps 43 48 from Volume 3 of the PALEOMAP Atlas for ArcGIS (Jurassic and Triassic) and maps $49-$ 52 from Volume 4 of the PALEOMAP PaleoAtlas for ArcGIS (Late Paleozoic), Mollweide Projecti.

Senowbari-Daryan, B., 1981. Zur Paläontologie eines kleinen Riffes innerhalb der AmphyclinenSchichten. Razpr. 4, Razreda SAZU 23, 99-118.

Senowbari-Daryan, B., 1984. Mikroproblematika aus den obertriadischen Riffkalken von Sizilien. Münster. Forsch. Geol. Paläont. 61, 1-81.

Senowbari-Daryan, B., 1990. Die systematische Stellung der thalamiden Schwämme und ihre Bedeutung in der Erdgeschichte.

Senowbari-Daryan, B., 2003. Peronidellen (Schwämme) aus der Trias und Beschreibung von Peronidella iranica n. sp. aus der Obertrias (Nor-Rhät) des Iran und von Österreich. Jahrb. der Geol. Bundesanstalt 143, 63-72.

Senowbari-Daryan, B., 2005. Hypercalcified sphinctozoan sponges from Upper Triassic NorianRhaetian) reefs of the Nayband Formation (Central and Northeast Iran). Jahrb. der Geol. Bundesanstalt 145, 171-277.

Senowbari-Daryan, B., 2009. Coralline Schwämme aus dem norisch-rhätischen Dachstein-Riff des Gosaukammes (Nördliche Kalkalpen, Österreich). Jahrb. der Geol. Bundesanstalt 149, 111-166.

Senowbari-Daryan, B., 2013. Tubiphytes Maslov, 1956 and description of similar organisms from Triassic reefs of the Tethys. Facies 59, 75-112.

Senowbari-Daryan, B., Amirhassankhani, F., 2013. Lovcenipora iranica nov. sp., an unusually large chaetetid sponge from the Upper Triassic (Howz-e Khan member, Nayband Formation) of northeast Iran. Zitteliana 15-22.

Senowbari-Daryan, B., Bernecker, M., 2009. Carnian (Upper Triassic) reef biota from limestone blocks of different tectonic settings in Oman. Beringeria 40, 3-53.

Senowbari-Daryan, B., Bernecker, M., Krystyn, L., Siblik, M., 1999. Carnian reef biota from a 
megabreccia of the Hawasina complex (Al Aqil, Oman). Riv. Ital. Di Paleontol. E Stratigr. 105, $327-342$.

Senowbari-Daryan, B., Di Stefano, P., Abate, B., 2015. Hypercalcified sponges from the Upper Triassic (Norian-Rhaetian) reefs of Sicily, Qauderni d. ed.

Senowbari-Daryan, B., García-Bellido, D.C., 2002. Fossil "Sphinctozoa": chambered sponges (polyphyletic), in: Systema Porifera. Springer, pp. 1511-1538.

Senowbari-daryan, B., Hamadani, A., 1999. Thalamid sponges from the Upper Triassic (NorianRhaetian) Nayband Formation near Wali-Abad, SE Abadeh, Central Iran. Riv. Ital. di Paleontol. e Stratigr. 105, 79-100.

Senowbari-Daryan, B., Hamadani, A., 2000. Obertriadische (Nor) Dasycladaceen aus der NaybandFormation vom Zentraliran. Rev. Paléobiologie 19, 97-121.

Senowbari-Daryan, B., Link, M., 1998. A new thalamid sponge from the Upper Triassic (Norian) reef limestones of the Antalya region (Turkey). Acta Geol Hungarica 42, 343-354.

Senowbari-Daryan, B., Link, M., 2005. Solenoporaceen aus den obertriassischen (Nor) Riffkalken des Taurusgebirges (Antalya-Gebiet, Südtürkei). Paläontologische Zeitschrift 79, 409-427.

Senowbari-Daryan, B., Link, M., 2011. Hypercalcified segmented sponges ("sphinctozoans") from the Upper Triassic (Norian) reef boulders of Taurus Mountains (southern Turkey). Facies 57, 663 693.

Senowbari-Daryan, B., Link, M., 2014. Bicoelia corticifera, a new inozoid sponge from the Upper Triassic (Norian) reef boulders of the Central Taurids (southern Turkey). Turkish J. Earth Sci. $23,575-579$.

Senowbari-Daryan, B., Link, M., Garcia-Bellido, D.C., 2003. Fanthalamia kadiri n. sp., a new“ Sphinctozoan" sponge from the Triassic (Carnian) of Turkey. Stud. UBB, Geol. 48, 125-131.

Senowbari-Daryan, B., Rashidi, K., Amirzadeh, M., Saberzadeh, B., Talebi, A., 2011. Sponges from the Upper Triassic (Norian-Rhaetian) Nayband Formation, Northeast Iran. Jb. Geol. BA Wien 347-355.

Senowbari-Daryan, B., Rashidi, K., Torabi, H., 2010. Foraminifera and their associations of a possibly Rhaetian section of the Nayband Formation in central Iran, northeast of Esfahan. Facies 56, 567596.

Senowbari-Daryan, B., Reid, R.P., 1987. Upper Triassic sponges (sphinctozoa) from southern Yukon, Stikinia terrane. Can. J. Earth Sci. 24, 882-902.

Senowbari-Daryan, B., Reitner, J., Neuweiler, F., Gunkel, F., 1996. Upper Triassic reefs and reef communities of Iran. Glob. Reg. Control. Biog. Sedimentation. Gottinger Arb. Geol. und Paläontologie Sb2 299-304.

Senowbari-Daryan, B., Schäfer, P., 1983. Zur Sphinctozoen-Fauna der obertriadischen Riffkalke ("Pantokratorkalke") von Hydra, Griechenland. Geol. Palaeontol. 17, 179-205.

Senowbari-Daryan, B., Schäfer, P., 1986. Sphinctozoen (Kalkschwämme) aus den norischen Riffen von Sizilien. Facies 14, 235-283.

Senowbari-Daryan, B., Schäfer, P., Abate, B., 1982. Obertriadische Riffe und Rifforganismen in Sizilien (Beiträge zur Paläontologie und Mikrofazies obertriadischer Riffe im alpin-mediterranen Raum, 27). Facies 6, 165-183.

Senowbari-Daryan, B., Seyed-Emami, K., Aghanabati, A., 1997. Some Inozoid sponges from Upper Triassic (Norian-Rhaetian) Nayband Formation of Central Iran. Riv. Ital. di Paleontol. e Stratigr. 103, 293-322.

Senowbari-Daryan, B., Stanley Jr, G.D., Onoue, T., 2012. Upper Triassic (Carnian) reef biota from the 
Sambosan Accretionary Complex, Kyushu, Japan. Facies 58, 671-684.

Shi, G.R., 1993. Multivariate data analysis in palaeoecology and palaeobiogeography—a review. Palaeogeogr. Palaeoclimatol. Palaeoecol. 105, 199-234.

Simpson, G.G., 1960. Notes on the measurement of faunal resemblance. Am. J. Sci. 258, 300-311.

Smith, A.B., 1988. Late Palaeozoic biogeography of East Asia and palaeontological constraints on plate tectonic reconstructions [and discussion]. Philos. Trans. R. Soc. London A Math. Phys. Eng. Sci. 326, 189-227.

Smith, P.L., Westermann, G.E.G., 1990. Paleobiogeography of the Ancient Pacific. Science (80-. ). $249,680-683$.

Stanley, G.D., Gonzalezleon, C., Sandy, M.R., Senowbaridaryan, B., Doyle, P., Tamura, M., Erwin, D.H., 1994. Upper Triassic Invertebrates from the Antimonio Formation, Sonora, Mexico. J. Paleontol. 68, 1-33.

Stanley, G.D., Senowbari-Daryan, B., 1986. Upper Triassic, Dachstein-type, reef limestone from the Wallowa Mountains, Oregon,; first reported occurrence in the United States. Palaios 1, 172-177.

Stanley, G.D., Yancey, T.E., 1990. In Reply: Paleobiogeography of the Ancient Pacific. Science (80-. ). 249, 680-681.

Stanley Jr, G.D., 1979. Paleoecology, structure, and distribution of Triassic coral buildups in western North America. The Paleontological Institute, The University of Kansas.

Stanley Jr, G.D., 1988. The history of early Mesozoic reef communities: a three-step process. Palaios $170-183$.

Stanley Jr, G.D., 1994. Late Paleozoic and early Mesozoic reef-building organisms and paleogeography: the Tethyan-North American connection. Cour. Forschungsinstitut Senkenb. 172, 69-75.

Stanley Jr, G.D., Onoue, T., 2015. Upper Triassic reef corals from the Sambosan Accretionary Complex, Kyushu, Japan. Facies 61, 1-27.

Stanton Jr, R.J., Flügel, E., 1987. Palecology of Upper Triassic reefs in the Northern Calcareous Alps: reef communities. Facies 16, 157-185.

Tamura, M., 1990. The distribution of Japanese Triassic bivalve faunas with special reference to parallel distribution of inner Arcto-Pacific fauna and outer Tethyan fauna in Upper Triassic. PreCretaceous Terranes of Japan 347-359.

Tamura, M., 1992. Difference between the Kochigatani and Tethyan bivalve faunas in the Late Triassic of Japan and its implication. J. Geol. Soc. Japan 98, 979-989.

Tosti, F., Mastandrea, A., Guido, A., Demasi, F., Russo, F., Riding, R., 2014. Biogeochemical and redox record of mid-late Triassic reef evolution in the Italian Dolomites. Palaeogeogr. Palaeoclimatol. Palaeoecol. 399, 52-66.

Tozer, E.T., 1982. Marine Triassic faunas of North America: their significance for assessing plate and terrane movements. Geol. Rundschau 71, 1077-1104.

Turnšek, D., Buser, S., Ogorelec, B., 1982. Carnian coral-sponge reefs in the Amphiclina beds between Hudajužna and Zakriž (western Slovenia). Razpr. 4, Razreda SAZU 24, 50-98.

Velledits, F., Pero, C., Blau, J., Senowbari-Daryan, B., 2011. The oldest Triassic platform margin reef from the alpine Carpathian region (Aggtelek, NE Hungary): platform evolution, reefal biota and biostratigraphic framework. Riv. Ital. di Paleontol. e Stratigr. 117, 221-268.

Vennin, E., Olivier, N., Brayard, A., Bour, I., Thomazo, C., Escarguel, G., Fara, E., Bylund, K.G., Jenks, J.F., Stephen, D.A., 2015. Microbial deposits in the aftermath of the end-Permian mass 
extinction: A diverging case from the Mineral Mountains (Utah, USA). Sedimentology 62, 753 792.

Veron, J.E.N., 1995. Corals in space and time: the biogeography and evolution of the Scleractinia. Cornell University Press.

Wolf, K.H., 1965. “Grain-diminution”of algal colonies to micrite. J. Sediment. Res. 35, 420-427.

Wolff, H., 1973. Fazies-Gliederung und Paläogeographie des Ladins in den bayerischen Kalkalpen zwischen Wendelstein und Kampenwand. Neues Jahrb. für Geol. und Paläontologie, Abhandlungen 143, 246-274.

Wurm, D., 1982. Mikrofazies, Paläontologie und Palökologie der Dachsteinriffkalke (Nor) des Gosaukammes, Österreich. Facies 6, 203-295.

Yamato Omine Research Group, 1976. Paleozoic and Mesozoic systems in the central area of the Kii Mountains, Southwest Japan (Part 1) geology around Mt Daifugen district, Nara prefecture . Earth Sci. 30, 260-267.

Yamato Omine Research Group, 1981. Paleozoic and Mesozoic Systems in the Central Area of the Kii Mountains, Southwest Japan Appendix 2 Mesozoic of the Sambosan Area in the Central Shikoku, Southwest Japan, in: Guide Book for the Excursion Prepared for the 35th Annual Meeting of the Association for the Geological Collaboration in Japan. pp. 68-88.

Yarnell, J.M., 2000. Paleontology of two North American Triassic reef faunas: Implications for terrane paleogeography.

Yoshida, A., Onoue, T., 2008. Lithostratigraphy, conodont ages, and oceanic plate stratigraphic correlation of deep-water pelagic limestone from Kutajima Island, Kagoshima, southwest Japan. J. Geol. Soc. Japan 114, 246.

Zaninetti, L., 1985. Orthotrinacria, n. gen.,(Protista: foraminiferida) from upper triassic (Norian) reefs of Sicily. Rev. Paléobiologie 4, 297-300. 


\section{Figure captions}

Fig. 1 Location maps of the studied localities. a Location of the Sambosan Accretionary Complex in southwestern Japan. b Location of studied areas in Shikoku. c-f Location of studied localities in Tsuno area (c), Mount Sambosan area (d), Befu and Kito area (e), Wajiki area (f).

Fig. 2 Mode of occurrence of reef limestone in the SAC. a Outcrop view of Mt. Sambosan showing a massive white limestone slab (Loc. 1 Mt. Sambosan 1) in fault contact (F) with VCM breccia (Loc. 2 Mt. Sambosan 2). b Close up view of the VCM breccia showing reef limestone clasts (LC) embedded in volcaniclastic matrix (VCM).

Fig. 3 Conodonts. A Quadralella sp. CP59-1. B Carnepigondolella samueli CP59-5. C Carnepigondolella cf. spatulata CP59-4. D Quadralella lobata CP59-9. E ? Quadralella sp. CP212-3. F ? Quadralella sp. CP213-9. G Primatella stanleyi CP213-4. H Krassodontus roberti alpha morphotype CP214-5. I Parvigondolella? sp. CP104.

Fig. 4 Reef biota of the SAC. a-f Foraminifers. a Duostominid CP212. b Galeanella sp. CP74. c Sessile foraminifer Planiinvoluta carinata (arrow) that encrusts a sponge (S) CP178. d Decapoalina schaeferae CP75. e Cucurbita infundibuliforme CP181. f Sessile foraminifer Flatschkofelia anisica CP178. g-l Microproblematica. g Baccanella floriformis in a reef limestone clast set in volcaniclastic matrix (VCM) CP215. h Actinotubella gusici CP6. i Ladinella porata JC383A. j Radiomura cautica CP222. k Microtubus communis CP6. I Asssociation of Microproblematica Tubiphytes sp. (T) and sponges Celyphia? minima (C) CP23. 
Fig. 5 Reef biota of the SAC. a-b Brachiopods. a Free-living brachiopod CP212. b Sessile brachiopod Gosaukammerella eomesozoica CP178. c Gastropod CP20. d Agglutinated worm tube Terebella sp. CP74. e-f Colonial serpulids Filograna sp. CP212. g Chaetetid sponge CP8.

Fig. 6 Dendrogram showing the results of a hierarchical cluster analysis (UPGMA, Dice coefficient of similarity) based on the occurrences of calcareous sponges, microproblematica and foraminifers in the studied localities of the SAC.

Fig. 7 Relative abundances of reef components. Components with relative abundance below $1 \%$ are not display in the pie charts.

Fig. 8 Reef microfacies. a-b Reef facies Type 1 (Ladinian?-Carnian), note the abundance of Tubiphytes and Microproblematica, CP24B. c-d Reef facies Type 2 (Upper Carnian-Norian), note the presence of Microtubus communis in microbial crust and the abundance of chaetetid sponges, IR6.

Fig. 9 Reef generic richness in Tethys and Panthalassa.

Fig. 10 Dendrogram showing the results of a hierarchical cluster analysis (UPGMA, Dice coefficient of similarity) based on the occurrences of calcareous sponges, microproblematica and foraminifers in the reef areas of Tethys and Panthalassa.

Fig. 11 Paleogeographic maps showing location of investigated reef areas (modified after Scotese, 2014). a Ladinian-Carnian reefs localities. b Norian-Rhaetian reef localities. Do: 
Dolomites; Gr: Greece; Hu: Hungary; Ir: Iran; Ja: Japan; NCA: Northern Calcareous Alps; Om: Oman; Or: Oregon; Si: Sicily; Sl: Slovenia; Tu: Turkey; Y: Yukon. 

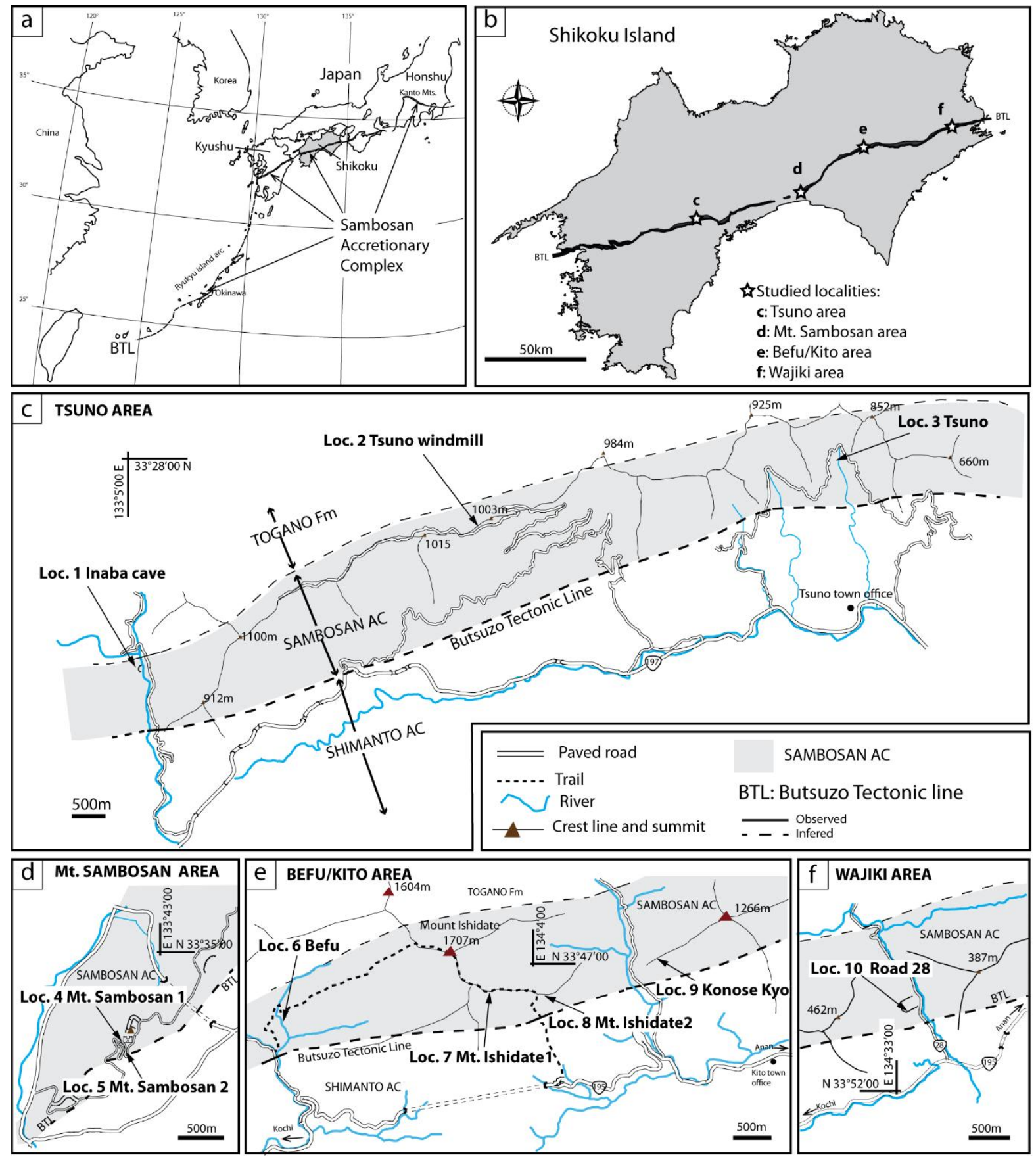

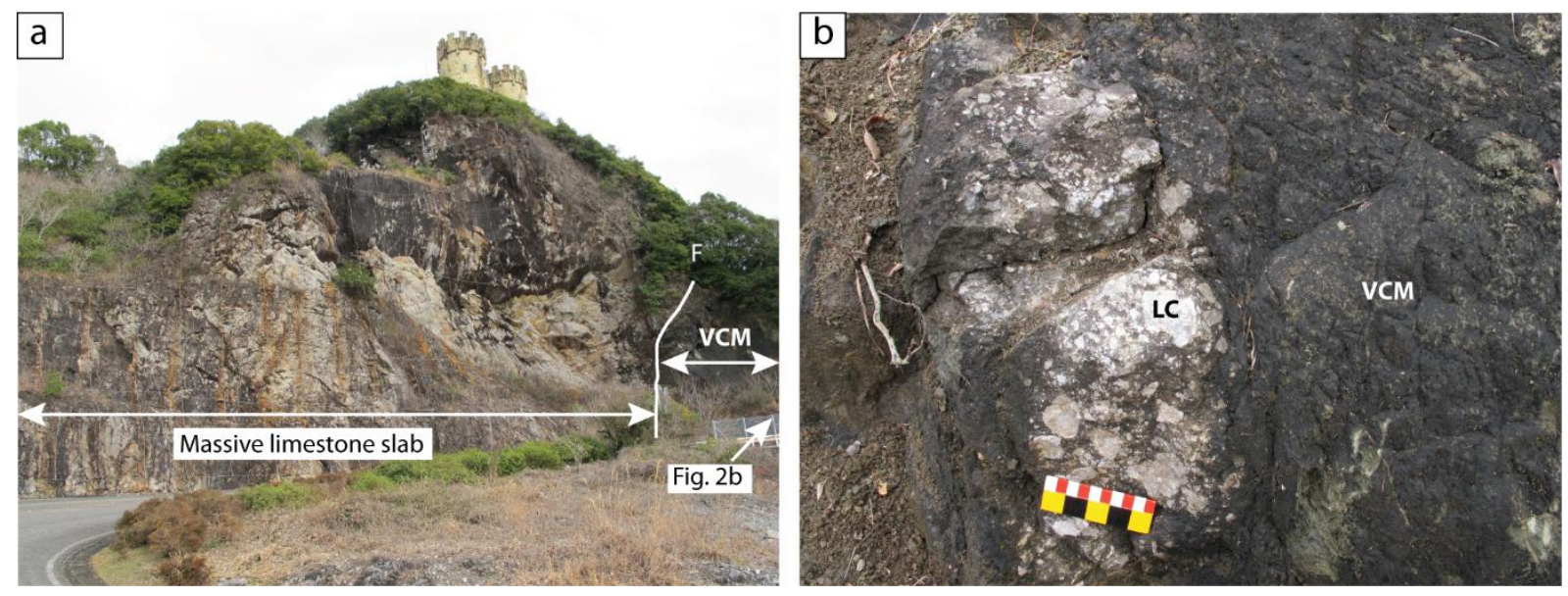


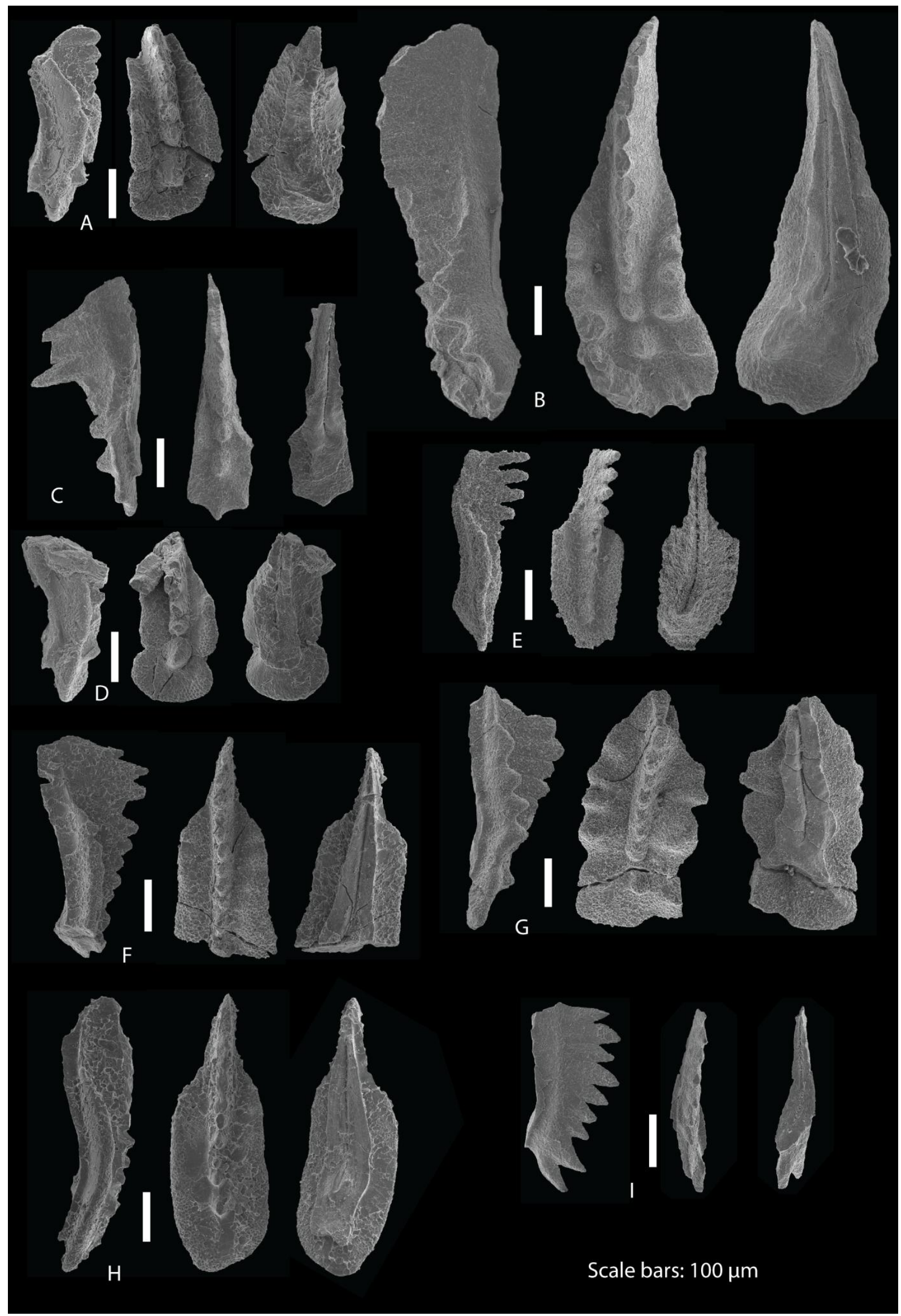



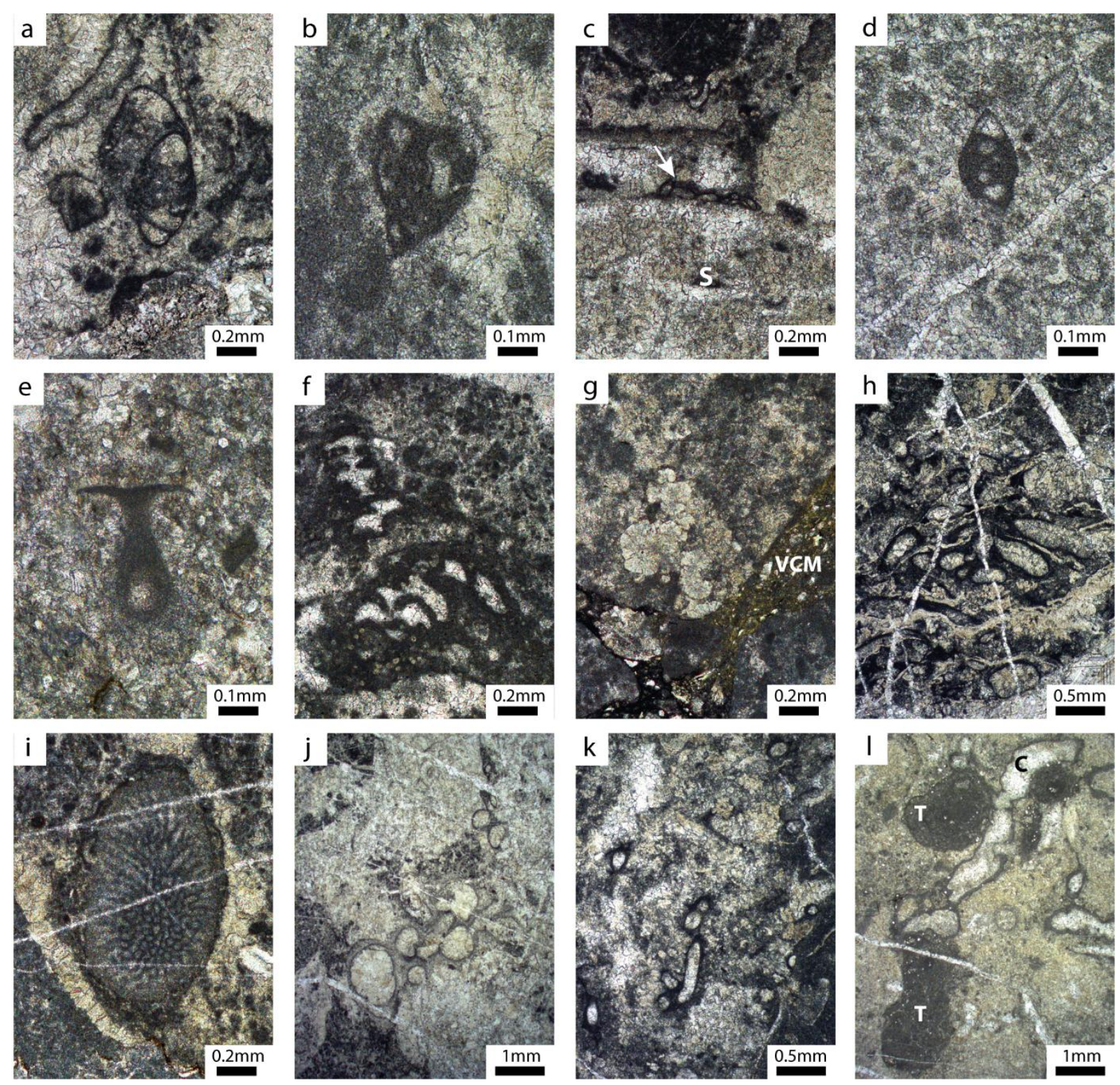

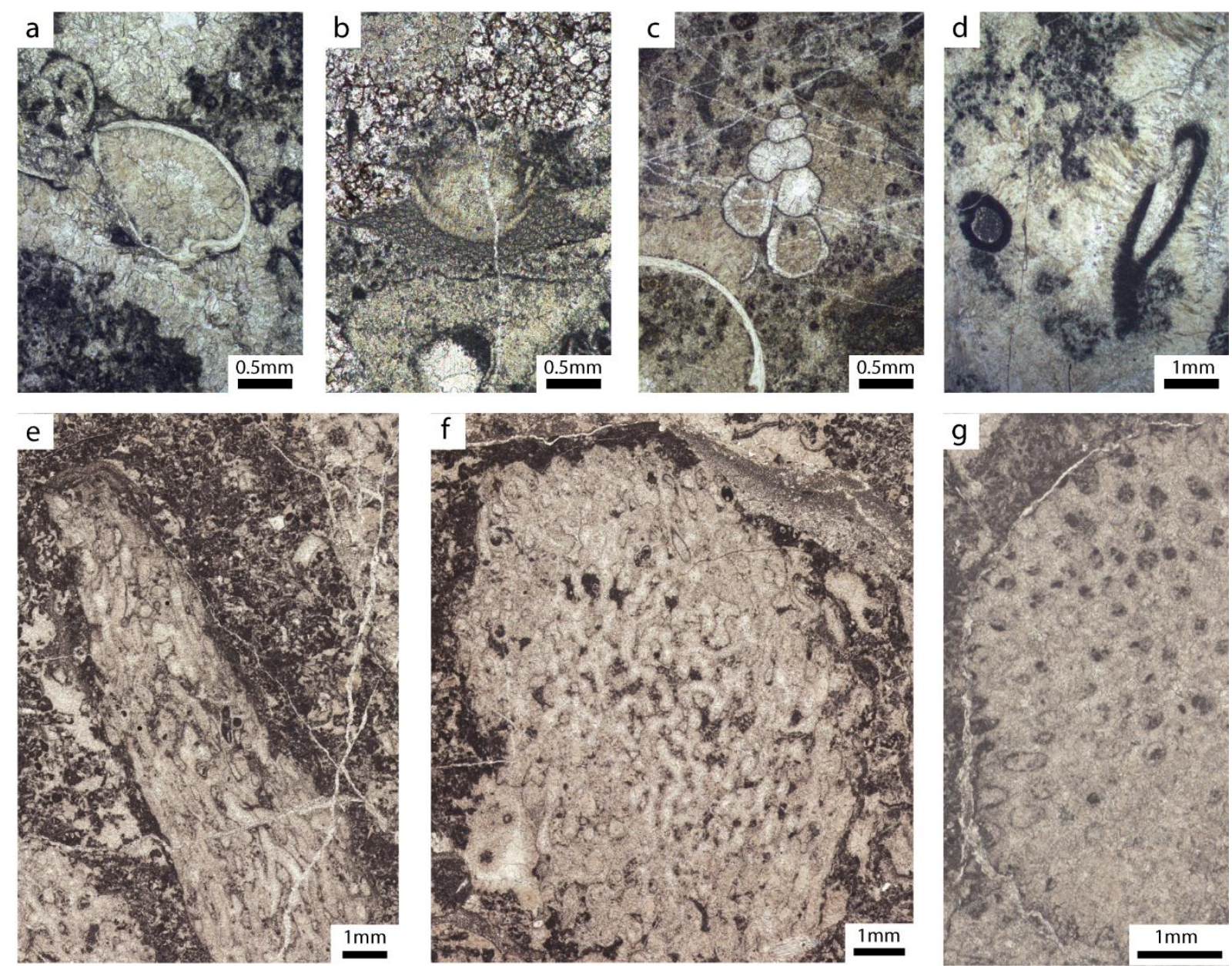


\section{Similarity (DICE)}
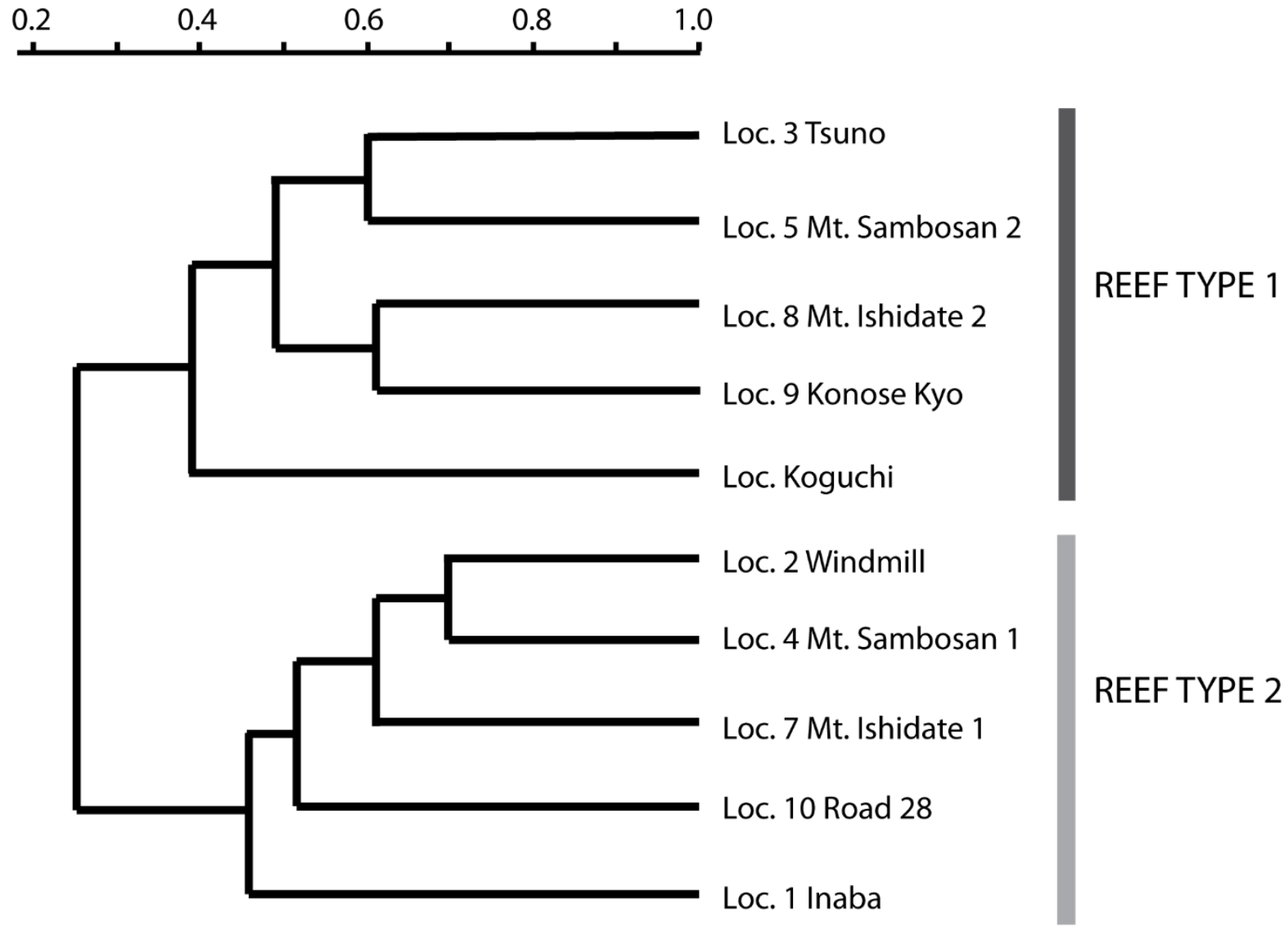

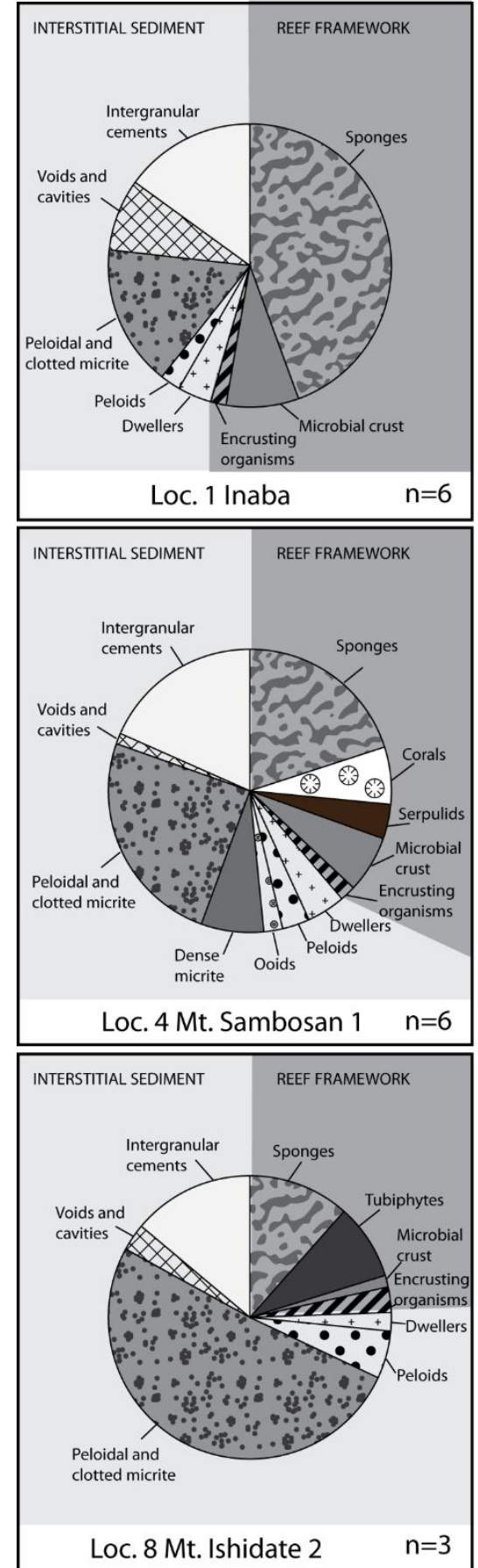
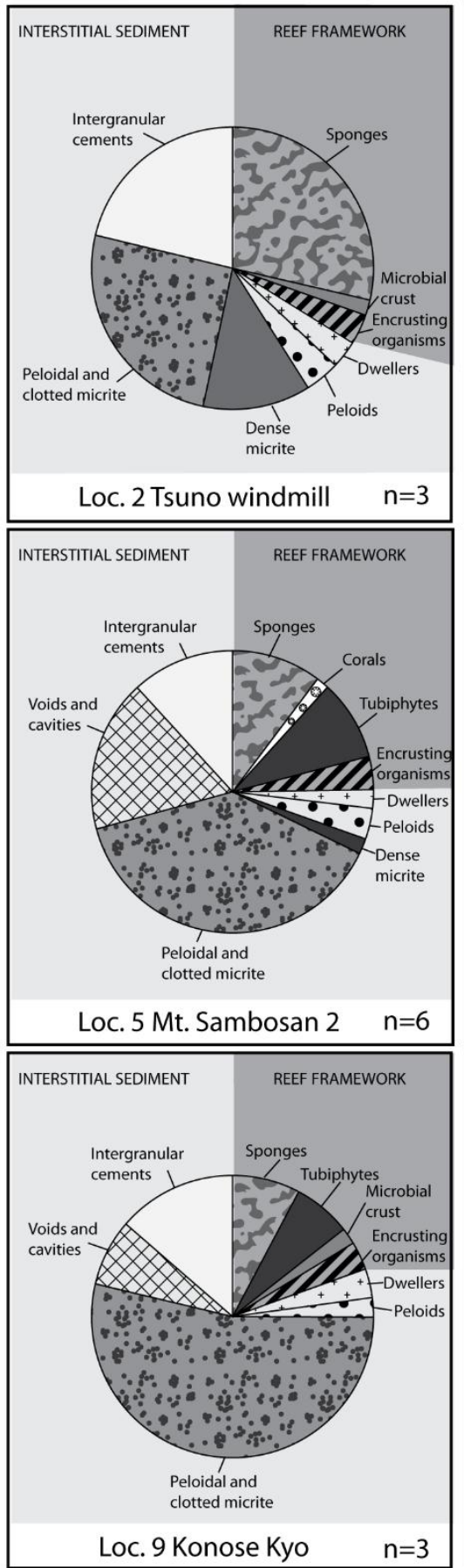
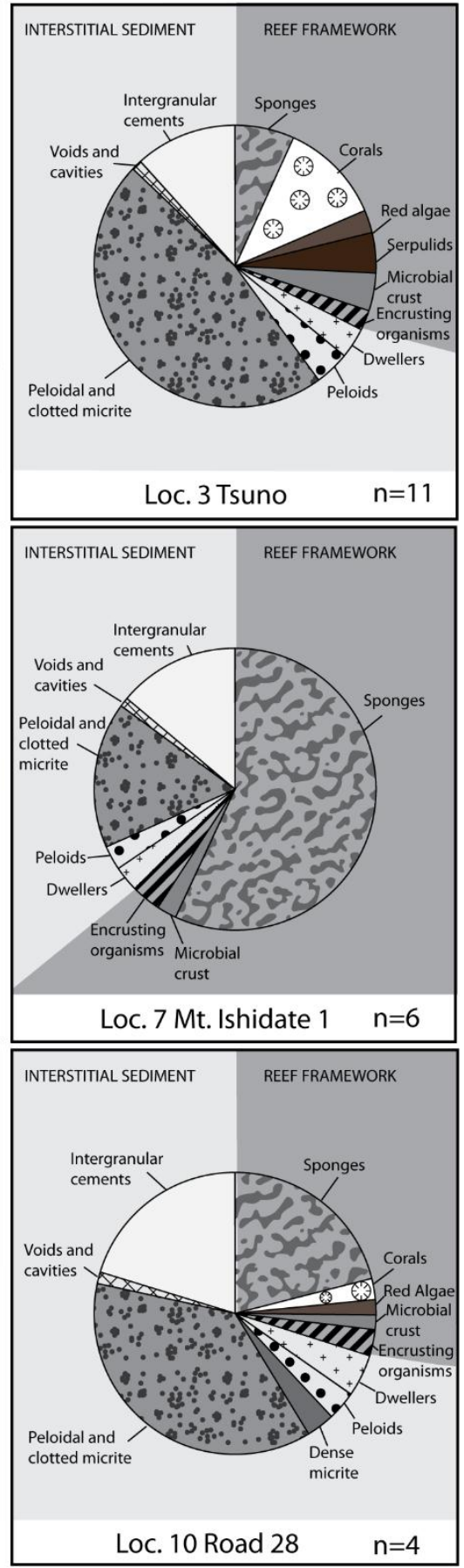

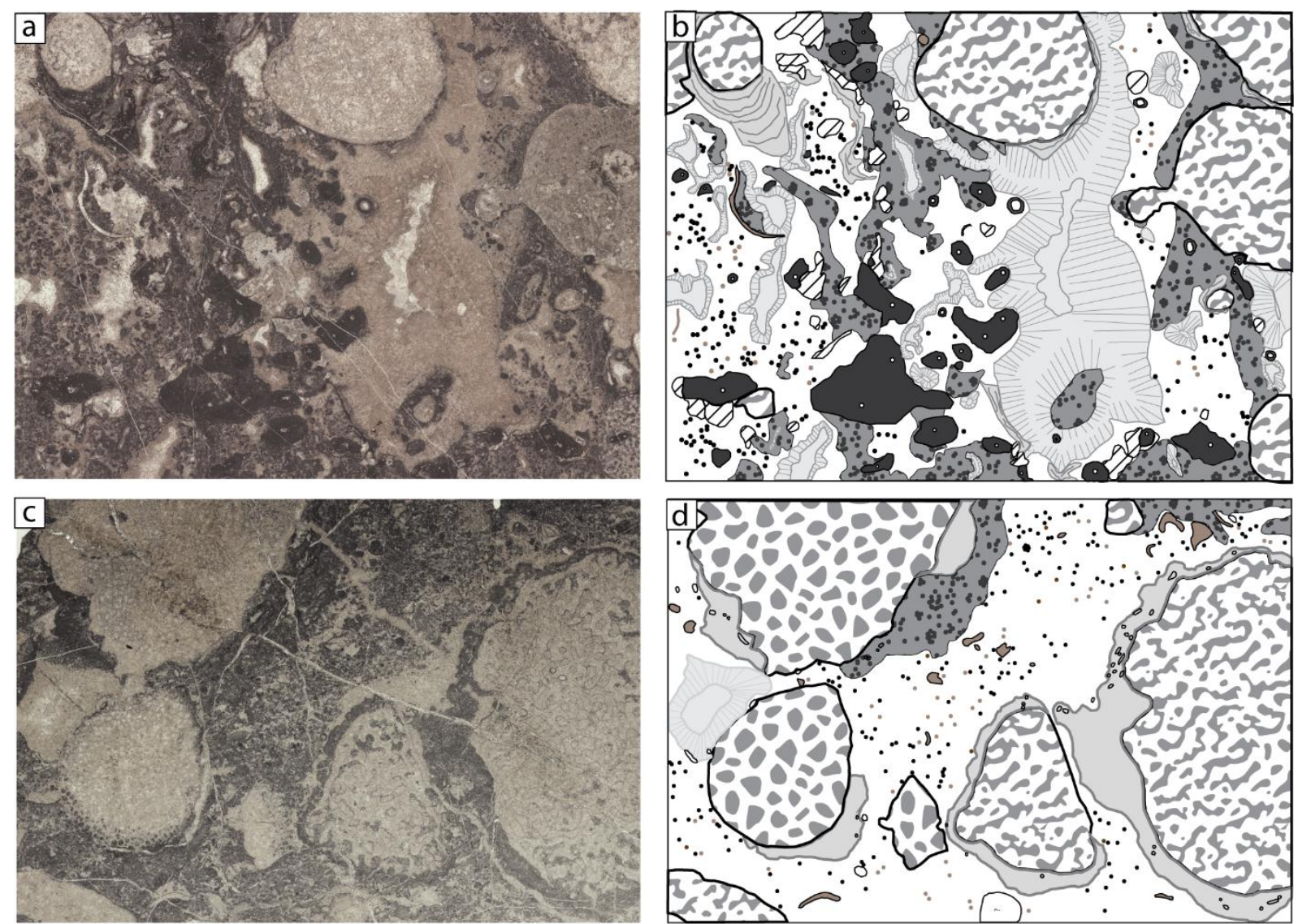

$0.5 \mathrm{~cm}$

REEF FRAMEWORK
Primary framebuilders

Microproblematica
Terebella sp.
Oeloids
Ooids




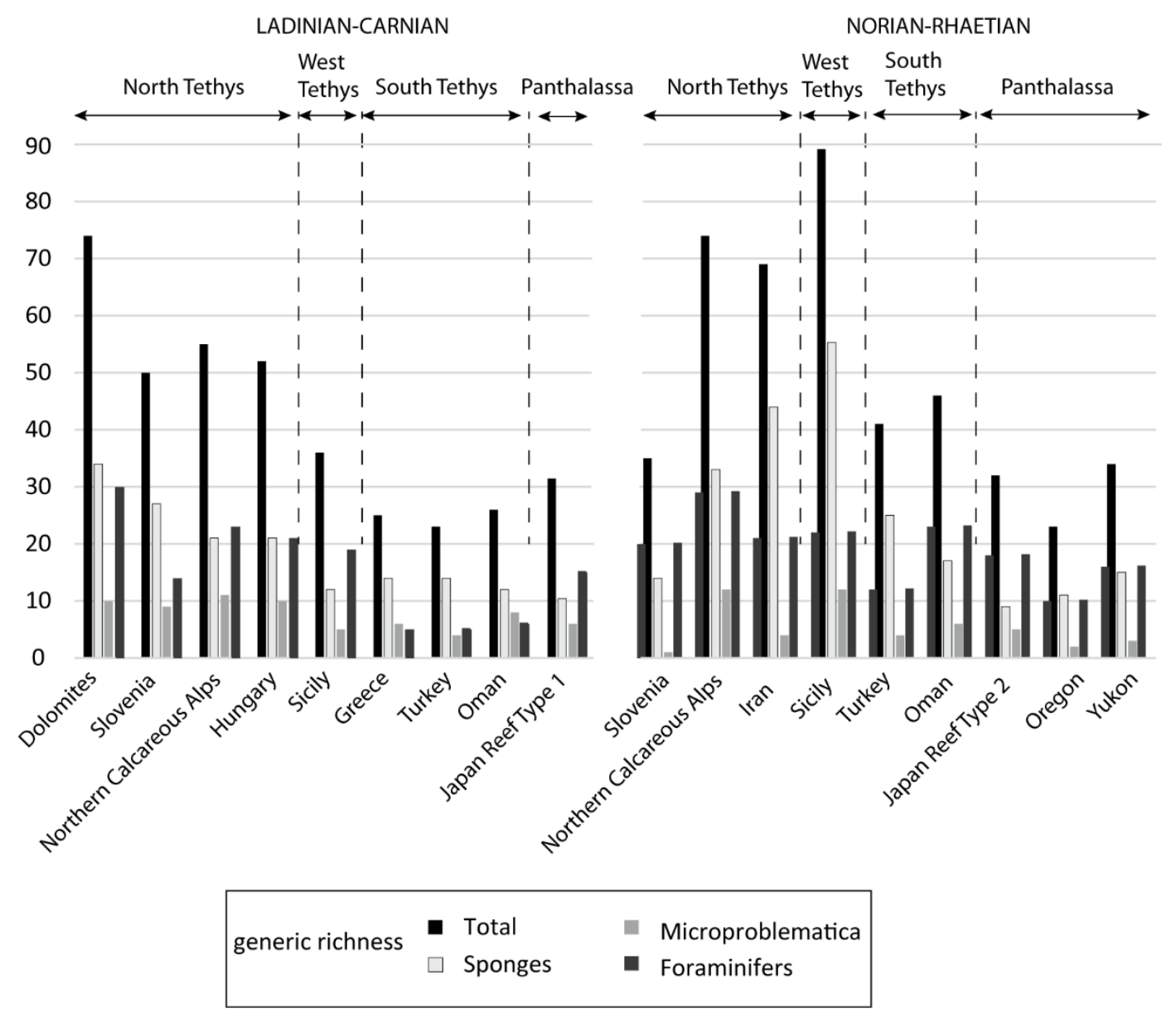




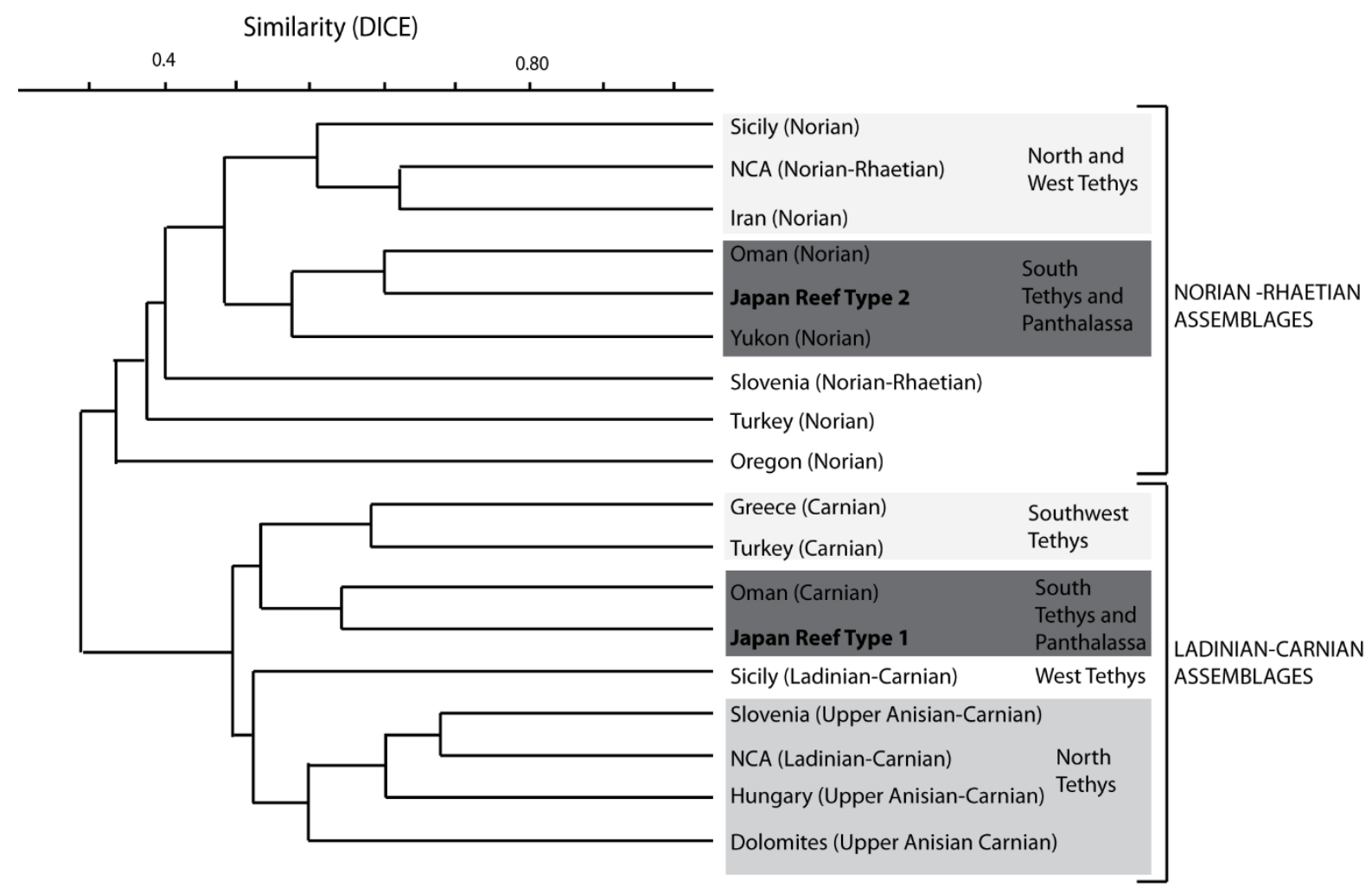



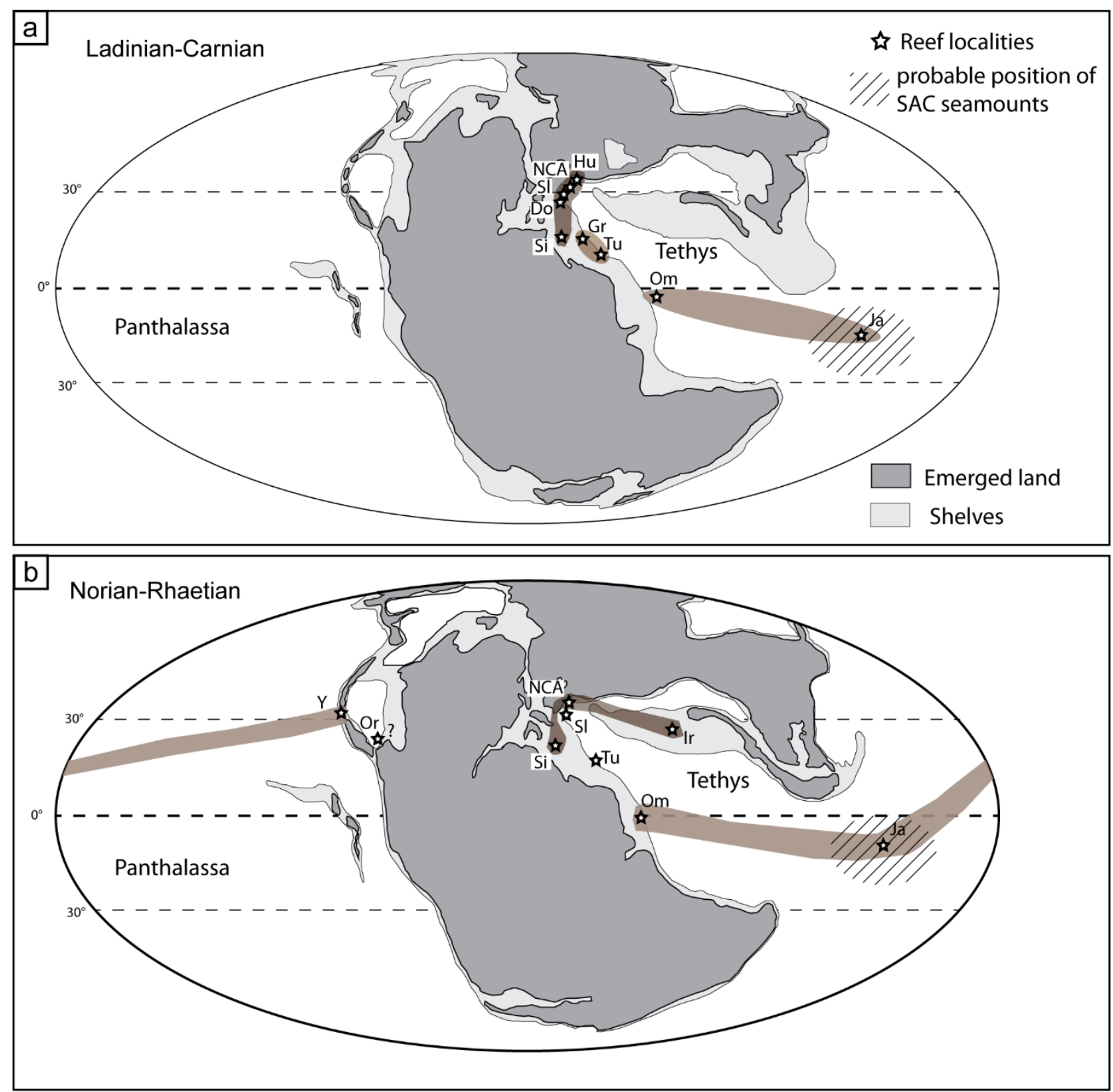
Table 1: Studied localities.

\begin{tabular}{|c|c|c|c|c|}
\hline & Locality & Coordinates & Mode of occurrence & Samples \\
\hline \multirow{3}{*}{$\begin{array}{l}\text { Tsuno area } \\
\text { (Tsuno, Kochi } \\
\text { prefecture) }\end{array}$} & Loc. 1 Inaba & $\begin{array}{l}33^{\circ} 26.322^{\prime} \mathrm{N} \\
133^{\circ} 5.134^{\prime} \mathrm{E}\end{array}$ & $\begin{array}{l}\text { Massive limestone } \\
\text { slab }\end{array}$ & $\begin{array}{l}\text { JC292-JC305, JC_IR1- } \\
\text { JC_IR31 }\end{array}$ \\
\hline & $\begin{array}{l}\text { Loc. } 2 \text { Tsuno } \\
\text { windmill }\end{array}$ & $\begin{array}{l}33^{\circ} 27.437^{\prime} \mathrm{N} \\
133^{\circ} 8.356^{\prime} \mathrm{E}\end{array}$ & $\begin{array}{l}\text { Massive limestone } \\
\text { slab }\end{array}$ & CP220-CP224 \\
\hline & Loc. 3 Tsuno & $\begin{array}{r}33^{\circ} 27.996^{\prime} \mathrm{N} \\
133^{\circ} 11.775^{\prime} \mathrm{E} \\
\end{array}$ & $\begin{array}{l}\text { Limestone clasts in } \\
\text { VCM breccia }\end{array}$ & CP120-CP132 \\
\hline \multirow[t]{2}{*}{$\begin{array}{l}\text { Mount Sambosan area } \\
\text { (Konan, Kochi } \\
\text { prefecture) }\end{array}$} & $\begin{array}{l}\text { Loc. } 4 \mathrm{Mt} . \\
\text { Sambosan1 }\end{array}$ & $\begin{array}{c}33^{\circ} 34.482^{\prime} \mathrm{N} \\
133^{\circ} 42.686^{\prime} \mathrm{E}\end{array}$ & $\begin{array}{l}\text { Massive limestone } \\
\text { slab }\end{array}$ & $\begin{array}{l}\text { CP6-CP13, CP27, CP212-214, } \\
\text { JC309-310, JC318-319, } \\
\text { JC322, JC328-327, JC332 }\end{array}$ \\
\hline & $\begin{array}{l}\text { Loc. } 5 \text { Mt. } \\
\text { Sambosan } 2\end{array}$ & $\begin{array}{r}33^{\circ} 34.452^{\prime} \mathrm{N} \\
133^{\circ} 42.733^{\prime} \mathrm{E} \\
\end{array}$ & $\begin{array}{l}\text { Limestone clasts in } \\
\text { VCM breccia }\end{array}$ & $\begin{array}{l}\text { CP15, CP18, CP20-25, } \\
\text { CP215, JC325 }\end{array}$ \\
\hline \multirow{4}{*}{$\begin{array}{c}\text { Befu/Kito area } \\
\text { (Kami, Kochi } \\
\text { prefecture and Naka, } \\
\text { Tokushima Prefecture ) }\end{array}$} & Loc. 6 Befu & & $\begin{array}{c}\text { Massive limestone } \\
\text { slab }\end{array}$ & CP59 \\
\hline & $\begin{array}{l}\text { Loc. } 7 \mathrm{Mt} . \\
\text { Ishidate1 }\end{array}$ & $\begin{array}{l}33^{\circ} 46.808^{\prime} \mathrm{N} \\
134^{\circ} 3.586^{\prime} \mathrm{E} \\
\end{array}$ & $\begin{array}{l}\text { Massive limestone } \\
\text { slab }\end{array}$ & CP69, CP71-82 \\
\hline & $\begin{array}{l}\text { Loc. } 8 \mathrm{Mt} \\
\text { Ishidate2 }\end{array}$ & $\begin{array}{l}33^{\circ} 46.800^{\prime} \mathrm{N} \\
134^{\circ} 4.063^{\prime} \mathrm{E}\end{array}$ & $\begin{array}{l}\text { Limestone clasts in } \\
\text { VCM breccia }\end{array}$ & СР62, СР66 \\
\hline & $\begin{array}{l}\text { Loc. } 9 \\
\text { Konose kyo }\end{array}$ & $\begin{array}{l}33^{\circ} 47.009^{\prime} \mathrm{N} \\
134^{\circ} 4.969^{\prime} \mathrm{E}\end{array}$ & $\begin{array}{l}\text { Limestone clasts in } \\
\text { VCM breccia }\end{array}$ & CP40-41; JC381-385 \\
\hline $\begin{array}{c}\text { Wajiki area } \\
\text { (Anan, Tokushima } \\
\text { prefecture) }\end{array}$ & $\begin{array}{l}\text { Loc. } 10 \\
\operatorname{Road} 28\end{array}$ & $\begin{array}{l}33^{\circ} 52.516^{\prime} \mathrm{N} \\
134^{\circ} 33.078^{\prime} \mathrm{E}\end{array}$ & $\begin{array}{l}\text { Limestone clasts in } \\
\text { VCM breccia }\end{array}$ & CP178-179; CP181C \\
\hline
\end{tabular}


Table 2: Relative abundances of reef components.

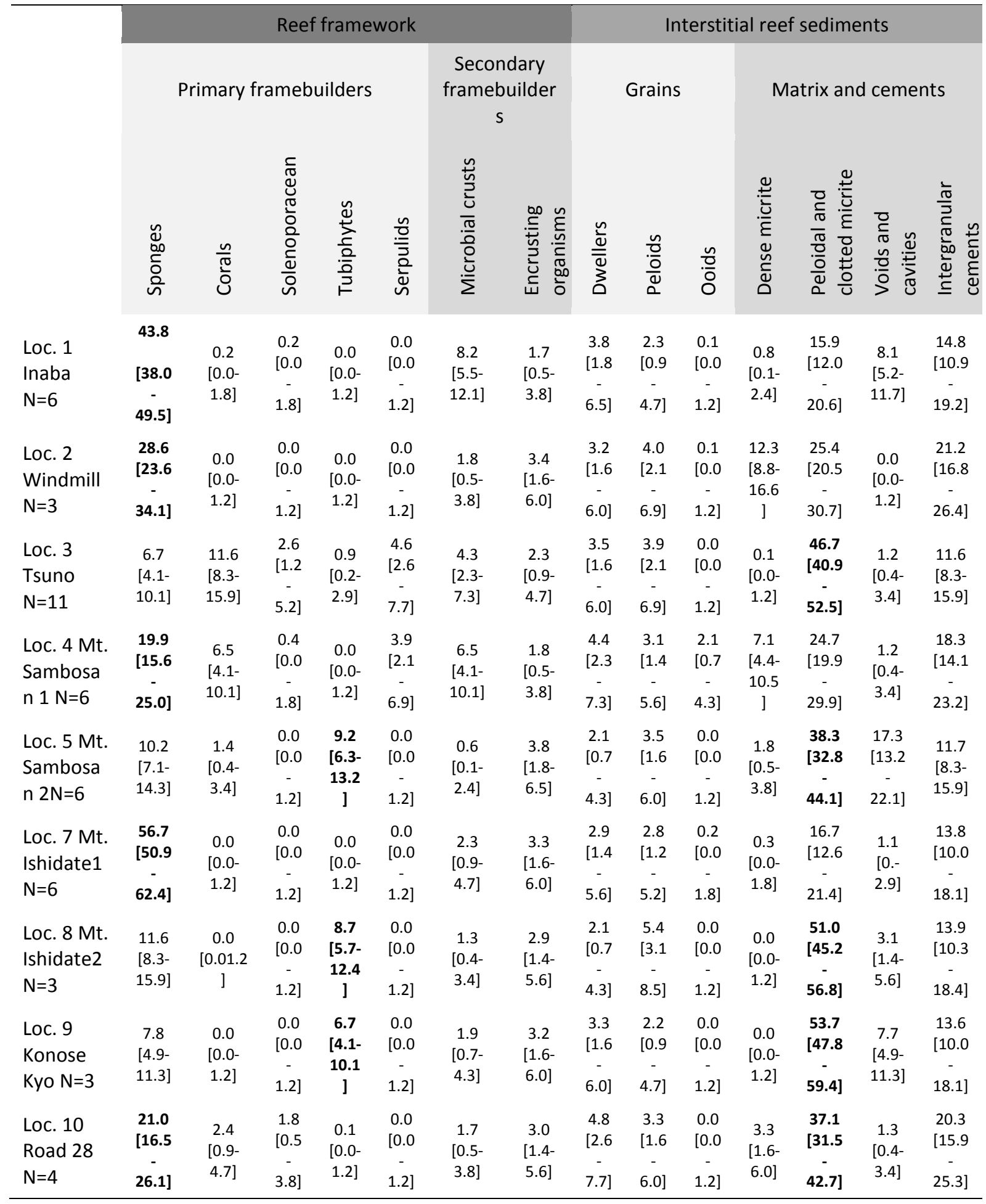

$\mathrm{N}$ : number of samples used for point-counting; Mean \% value [associated 95\% "exact" Clopper-

Pearson confidence interval]; Important value in bold 
Table 3: Relative abundance of reef framework and interstitial sediments.

\begin{tabular}{lcc}
\hline Localities & \%reef framework & \%interstitial sediments \\
\hline Loc. 1 Inaba & 54.2 & 45.8 \\
Loc. 2 Windmill & 33.8 & 66.2 \\
Loc.3 Tsuno & 33.0 & 67.0 \\
Loc. 4 Mt. Sambosan 1 & 39.0 & 61.0 \\
Loc. 5 Mt. Sambosan 2 & 25.2 & 74.8 \\
Loc. 7 Mt. Ishidate1 & 62.3 & 37.7 \\
Loc. 8 Mt. Ishidate2 & 24.4 & 75.6 \\
Loc. 9 Konose Kyo & 19.5 & 80.5 \\
Loc. 10 Road 28 & 29.9 & 70.1 \\
\hline
\end{tabular}


Table 4: Generic richness and references of the investigated reef fauna of the Tethys and Panthalassa.

\begin{tabular}{|c|c|c|c|c|c|c|}
\hline \multirow[b]{2}{*}{ Areas } & \multirow[b]{2}{*}{$\begin{array}{l}\text { Time } \\
\text { interval }\end{array}$} & \multicolumn{4}{|c|}{ Number of genera } & \multirow[b]{2}{*}{ References } \\
\hline & & $\underset{\stackrel{\Gamma}{\pi}}{\stackrel{\Gamma}{\circ}}$ & 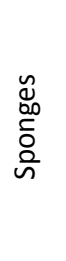 & 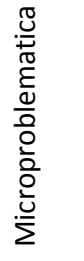 & 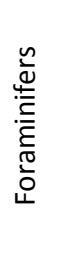 & \\
\hline $\begin{array}{l}\text { The } \\
\text { Dolomites } \\
\text { (Italy) }\end{array}$ & $\begin{array}{l}\text { Anisian- } \\
\text { Carnian }\end{array}$ & 74 & 34 & 10 & 30 & $\begin{array}{l}\text { Emmerich et al., 2005; Brandner, 1991; Sanchez-Beristain 2010; } \\
\text { Dieci et al., } 1968 \text {; Di Bari and Laghi, } 1994\end{array}$ \\
\hline Slovenia & $\begin{array}{l}\text { Upper } \\
\text { Anisian- } \\
\text { Carnian }\end{array}$ & 50 & 27 & 9 & 14 & $\begin{array}{l}\text { Flügel, 1986; Senowbari-Daryan, 1981; Buser et al., 1982; Turnsek } \\
\text { et al., 1982; Bole, 2002; Pfeiffer, } 1988\end{array}$ \\
\hline $\begin{array}{l}\text { Northern } \\
\text { Calcareous } \\
\text { Alps }\end{array}$ & $\begin{array}{l}\text { Ladinian- } \\
\text { Carnian }\end{array}$ & 55 & 21 & 11 & 23 & $\begin{array}{l}\text { Wolff, 1973; Ruffer and Zamparelli, 1997; Dullo and Lein, 1982; } \\
\text { Dullo et al., } 1987\end{array}$ \\
\hline Hungary & $\begin{array}{l}\text { Upper } \\
\text { Anisian- } \\
\text { Carnian }\end{array}$ & 52 & 21 & 10 & 21 & Velledits et al., 2011; Flügel et al., 1992 \\
\hline Sicily & $\begin{array}{l}\text { Ladinian- } \\
\text { Carnian } \\
\end{array}$ & 36 & 12 & 5 & 19 & Carillat and Martini, 2009; Boni et al., 1994 \\
\hline Greece & Carnian & 25 & 14 & 6 & 5 & $\begin{array}{l}\text { Senowbari-Daryan and Schäfer, 1983; Schäfer and Senowbari- } \\
\text { Daryan, 1982; Dragastan et al., } 1999\end{array}$ \\
\hline Turkey & Carnian & 23 & 14 & 4 & 5 & Gusic et al., 1984; Riedel, 1990; Senowbari-daryan et al., 2003 \\
\hline Oman & Carnian & 26 & 12 & 8 & 6 & $\begin{array}{l}\text { Senowbari daryan et al., 1999; Senowbari-Daryan and Bernecker, } \\
2009\end{array}$ \\
\hline $\begin{array}{l}\text { Japan Reef } \\
\text { Type } 1\end{array}$ & $\begin{array}{l}\text { Ladinian- } \\
\text { Carnian }\end{array}$ & 31 & 10 & 6 & 15 & Senowbari-Daryan et al., 2012; Peybernes et al., 2015 ; This work \\
\hline Slovenia & $\begin{array}{l}\text { Norian- } \\
\text { Rhaetian }\end{array}$ & 35 & 14 & 1 & 20 & Buser et al., 1982; Gale, 2012 ; Gale et al., 2013a \\
\hline $\begin{array}{l}\text { Northern } \\
\text { Calcareous } \\
\text { Alps }\end{array}$ & $\begin{array}{l}\text { Norian- } \\
\text { Rhaetian }\end{array}$ & 74 & 33 & 12 & 29 & $\begin{array}{l}\text { Bernecker, 2005; Martindale et al., 2013a; Senowbari-Daryan, } \\
2009\end{array}$ \\
\hline Iran & Norian & 69 & 44 & 4 & 21 & $\begin{array}{l}\text { Senowbari-Daryan, 2005; Senowbari-Daryan et al., 1996; } \\
\text { Senowbari-Drayan et al., 1997; Senowbari-Daryan and Hamadani, } \\
\text { 1999; Senowbari-Daryan, 2003; Senowbari-Daryan and Hamadani, } \\
\text { 2000; Senowbari-Daryan and Amirahssankhani, 2013; Senowbari- } \\
\text { Daryan et al., 2011; Senowbari-Daryan et al., } 2010\end{array}$ \\
\hline Sicily & Norian & 89 & 55 & 12 & 22 & $\begin{array}{l}\text { Senowbari-Daryan et al., 1982; Senowbari-Daryan, 1984; } \\
\text { Senowbari-Daryan and Schäfer, 1986; Senowbari-Daryan, 1990; } \\
\text { Zaninetti 1985; Di Stephano and Gullo, } 1990 \text {; Senowbari-Daryan } \\
\text { et al., } 2015\end{array}$ \\
\hline Turkey & Norian & 41 & 25 & 4 & 12 & $\begin{array}{l}\text { Senowbari-Daryan and Link, 2011; Senowbari-daryan and Link, } \\
\text { 1998; Senowbari-Daryan and Link 2005; Senowbari-Daryan et al., } \\
\text { 2003; Okay and Altiner, 2004; Senowbari-Daryan and Link, } 2014\end{array}$ \\
\hline Oman & Norian & 46 & 17 & 6 & 23 & Bernecker, 2005 \\
\hline $\begin{array}{l}\text { Japan Reef } \\
\text { Type } 2\end{array}$ & Norian & 32 & 9 & 5 & 18 & Chablais et al., 2010b; this work \\
\hline $\begin{array}{l}\text { Oregon } \\
\text { (USA) }\end{array}$ & Norian & 23 & 11 & 2 & 10 & Stanley and Senowbari-Daryan, 1986; Martindale et al., 2012 \\
\hline $\begin{array}{l}\text { Yukon } \\
\text { (Canada) }\end{array}$ & Norian & 34 & 15 & 3 & 16 & $\begin{array}{l}\text { Senowbari-Daryan and Reid, 1987; Reid, 1987; Gazdzicki and Reid, } \\
\text { 1983; Reid and Tempeleman-Kluit, } 1986\end{array}$ \\
\hline
\end{tabular}


Table 5 Characteristic and ages of the types of reef in the SAC of Shikoku.

\begin{tabular}{lll}
\hline & Reef Type 1 & Reef Type 2 \\
\hline Localities & Loc. 3 Tsuno, Loc. 5 Mt. Sambosan & Loc. 1 Inaba cave, Loc. 2 Tsuno \\
& 2, Loc. 8 Mt. Ishidate 2, Loc. 9 & windmill, Loc. 4 Mt. Sambosan 1, \\
& Konose Kyo & Loc. 7 Mt. Ishidate 1, Loc. 10 Road \\
& & 28
\end{tabular}

